\title{
Combining rimonabant and fentanyl in a single entity: preparation and pharmacological results
}

This article was published in the following Dove Press journal:

Drug Design, Development and Therapy

20 February 2014

Number of times this article has been viewed

\author{
Cristina Fernández- \\ Fernández' \\ Luis F Callado \\ Rocío Girón ${ }^{3}$ \\ Eva Sánchez ${ }^{3}$ \\ Amaia M Erdozain ${ }^{2}$ \\ José Antonio López- \\ Moreno ${ }^{4}$ \\ Paula Morales' \\ Fernando Rodríguez de \\ Fonseca $^{5}$ \\ Javier Fernández-Ruiz ${ }^{6}$ \\ Pilar Goya' \\ J Javier Meana ${ }^{2}$ \\ M Isabel Martín ${ }^{3}$ \\ Nadine Jagerovic' \\ 'Instituto de Química Médica, CSIC, \\ Madrid, ${ }^{2}$ Departamento de Farmacología, \\ Universidad del Pais Vasco, UPV/EHU \\ CIBERSAM, Leioa, ${ }^{3}$ Departamento de \\ Farmacología y Nutrición, Ciencias \\ de la Salud, Universidad Rey Juan \\ Carlos, Alcorcón, ${ }^{4}$ Departamento de \\ Psicobiologia, Universidad Complutense \\ de Madrid, Madrid, ${ }^{5}$ Laboratorio de \\ Medicina Regenerativa, Hospital Carlos \\ Haya, Fundación IMABIS, Málaga, \\ ${ }^{6}$ Departamento de Bioquímica y Biología \\ Molecular, Facultad de Medicina, \\ CIBERNED, IRYCIS, Universidad \\ Complutense de Madrid, Madrid, Spain
}

Correspondence: Nadine Jagerovic Instituto de Química Médica, CSIC, C/Juan de la Cierva 3, E-28006 Madrid, Spain

Tel +34 9 I562 2900

Fax +349 I564 4853

Email nadine@iqm.csic.es

\begin{abstract}
Based on numerous pharmacological studies that have revealed an interaction between cannabinoid and opioid systems at the molecular, neurochemical, and behavioral levels, a new series of hybrid molecules has been prepared by coupling the molecular features of two wellknown drugs, ie, rimonabant and fentanyl. The new compounds have been tested for their affinity and functionality regarding $\mathrm{CB}_{1}$ and $\mathrm{CB}_{2}$ cannabinoid and $\mu$ opioid receptors. In $\left.{ }^{35} \mathrm{~S}\right]-\mathrm{GTP} \gamma \mathrm{S}$ (guanosine 5'-O-[gamma-thio]triphosphate) binding assays from the post-mortem human frontal cortex, they proved to be $\mathrm{CB}_{1}$ cannabinoid antagonists and $\mu$ opioid antagonists. Interestingly, in vivo, the new compounds exhibited a significant dual antagonist action on the endocannabinoid and opioid systems.
\end{abstract}

Keywords: fentanyl, rimonabant, cannabinoid, opioid, behavioral assays

\section{Introduction}

Pharmacological data have revealed interactions between the cannabinoid and opioid systems at the molecular, neurochemical, and behavioral levels. ${ }^{1-7}$ Anatomical studies have shown that such pharmacological interactions are likely due to the close vicinity of $\mathrm{CB}_{1}$ and opioid receptors in the central nervous system structures involved in the control of nociception, motor activity, and brain reward. In this context, the development of a single molecule able to act on both the cannabinoid and opioid systems seems an interesting approach. Multivalent or multifunctional ligands constitute promising pharmacological tools and new targets for drug development. Moreover, targeting $\mathrm{G}$ protein-coupled receptors with hybrid molecules has been explored in different domains. The concept of hybridization has become of increasing interest for medicinal chemists. This strategy has resulted in promising leads that show significant therapeutic advantages. ${ }^{8,9}$ The main benefit compared with the administration of two drugs concerns the pharmacokinetic properties of a single molecule. In order to focus our efforts on an efficient designed multiple ligand approach, two well validated drugs were selected, ie, fentanyl and rimonabant (SR141716, Figure 1). Fentanyl is a synthetic $\mu$ opioid agonist widely used in clinical practice ${ }^{10}$ and rimonabant was the first selective $\mathrm{CB}_{1}$ cannabinoid receptor inverse agonist/antagonist to be approved for clinical use, ${ }^{11}$ even though its use was discontinued due to unwanted effects. ${ }^{12}$

Therefore, our aim was to explore the hybrid molecules represented in Figure $1(4 \mathrm{a}-\mathrm{k})$ based on previous structural modification studies carried out on fentanyl and rimonabant. Fentanyl derivatives (Figure 2), in which a phenyl was replaced by an aliphatic chain bearing a guanidine moiety, have shown high affinity for the $\mu$ opioid receptor, with agonistic properties. ${ }^{13,14}$ Concerning the cannabinoid counterpart of the proposed hybrid molecules, 
<smiles>Cc1c(C(=O)NN2CCCCC2)nn(-c2ccc(Cl)cc2Cl)c1-c1ccc(Cl)cc1</smiles><smiles>CCOC(=O)N(c1ccccc1)C1CCN(CCc2ccccc2)CC1</smiles>

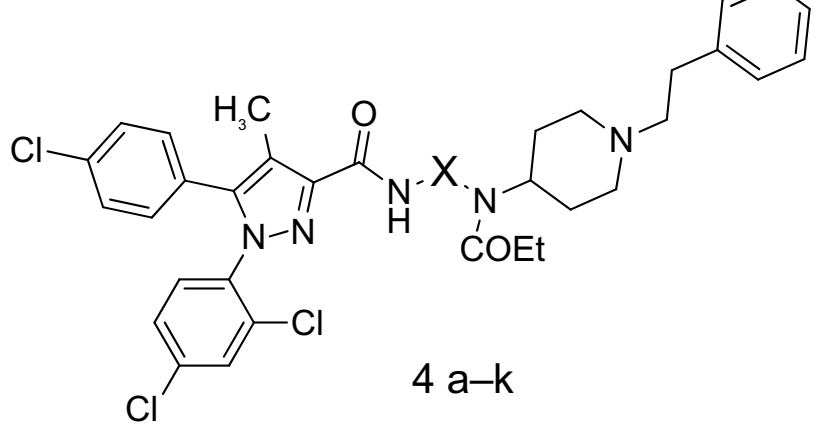

Figure I The designed multiple ligands are based on the $\mathrm{CB}_{1}$ cannabinoid receptor inverse agonist/antagonist rimonabant (SRI4I7/6) (Sanofi, Paris, France) and the $\mu$ opioid agonist fentanyl. ${ }^{13} \mathrm{X}$ represents an $n$-alkyl chain from propyl to dodecyl, I,3-phenyl, I,3-benzyl, or biscyclohex-4-ylmethane.

good affinities for the $\mathrm{CB}_{1}$ receptor have been reported for diarylcarboxamides bearing alkyl chains (Figure 2). ${ }^{15,16}$

Herein, we describe the synthesis, pharmacological profile, and behavioral effects in vivo of a series of hybrid molecules derived from fentanyl and rimonabant.

\section{Materials and methods}

\section{General}

All commercially available reagents were purchased from Sigma-Aldrich (Madrid, Spain) and used without further purification. Dry $\mathrm{CH}_{2} \mathrm{Cl}_{2}$ was obtained by distillation over calcium

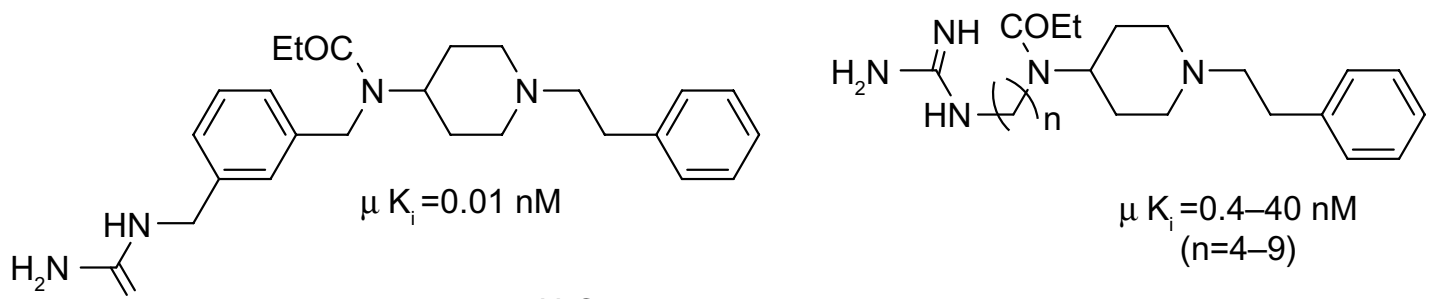

$\mathrm{NH}$<smiles>CCCCCCCNC(=O)c1n[nH]c(-c2ccc(Cl)cc2)c1C</smiles>

$\mathrm{CB}_{1} \mathrm{~K}_{\mathrm{i}}=290 \mathrm{nM}$

$\mathrm{Cl}^{\prime}$

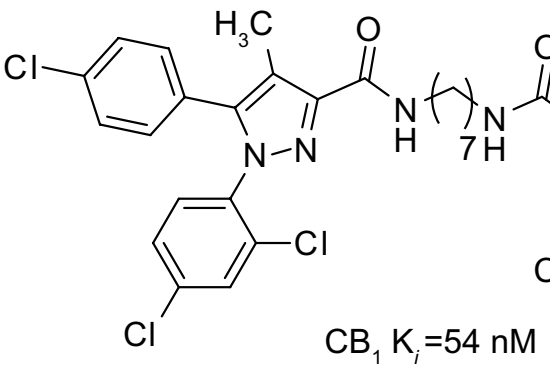<smiles>Cc1c(C(=O)C=O)nn(-c2ccc(Cl)cc2Cl)c1-c1ccc(Cl)cc1</smiles>

Figure 2 Examples of fentanyl derivatives with selective $\mu$ opioid agonistic properties and rimonabant derivatives with $C B_{1}$ receptor affinity Abbreviation: $\mathrm{K}_{i}$, affinity constant. 
chloride. Flash column chromatography was performed using silica gel 60 (230-400 mesh) or on a medium pressure flash system with a prepacked silica gel cartridge (Biotage Flash 40 [SYMTA, Madrid, Spain], cartridges KP-Sil 40S [4 $\times 7 \mathrm{~cm}$ ] or $4 \mathrm{M}[4 \times 15 \mathrm{~cm}]$ with a particle size of $32-63 \mu \mathrm{m}$ and $60 \AA$; FlashMaster Personal [SYMTA] with prepacked cartridges FlashPack of 2, 10, 20 or $50 \mathrm{~g}$ ). Starting products 1 and 2 were prepared as previously described. ${ }^{17} N$-[1-phenethyl-4-piperidyl]propanamide $3 \mathrm{a}-3 \mathrm{k}$ were prepared following a procedure previously described by our group..$^{13,18}$

\section{Chemistry}

Compounds $4 \mathrm{a}-4 \mathrm{k}$ were prepared following the synthetic route depicted in Figure 3. Diaryl-1H-pyrazole-3-carboxylic acid 1 was previously prepared according to Krishnamurthy's procedure. ${ }^{19}$ Next, pyrazole 1 was converted to the acid chloride 2 using the following procedure. A solution of the appropriate propanamide $3 \mathrm{a}-3 \mathrm{k}$ and triethylamine in dry $\mathrm{CH}_{2} \mathrm{Cl}_{2}$ was added dropwise to pyrazole-3-carboxylic acid chloride 2 dissolved in dry $\mathrm{CH}_{2} \mathrm{Cl}_{2}(5 \mathrm{~mL})$. The reaction mixture was stirred at room temperature for 16 hours. The solvent was then removed under reduced pressure. The crude product was purified on silica gel by flash chromatography eluting with $\mathrm{CH}_{2} \mathrm{Cl}_{2} /\left(\mathrm{MeOH} / \mathrm{NH}_{3}\right)(100: 0-100: 2)$ to provide the corresponding pyrazole-3-carboxamides $4 \mathrm{a}-4 \mathrm{k}$. The yields of the preparation and the structural assignments of $4 \mathrm{a}-4 \mathrm{k}$ are reported in the Supplementary material section ( ${ }^{1} \mathrm{H}-\mathrm{NMR}$ [nuclear magnetic resonance], ${ }^{13} \mathrm{C}-\mathrm{NMR}$, MS [mass spectroscopy], and elemental analysis).

\section{Pharmacology}

Post-mortem human brain $\mathrm{CB}_{\text {I }}$ and $\mu$ opioid binding assays

The ability of the new compounds to bind to the $\mathrm{CB}_{1}$ cannabinoid receptors and to the $\mu$ opioid receptor was evaluated in competitive displacement assays using, respectively, $\left[{ }^{3} \mathrm{H}\right]-\mathrm{CP} 55,940$ (PerkinElmer, Boston, MA, USA) and [ $\left.{ }^{3} \mathrm{H}\right]-\mathrm{DAMGO}$ ([DAla ${ }^{2}, \mathrm{~N}$-Me-Phe ${ }^{4}, \mathrm{Gly}^{5}$-ol]-enkephalin; American Radiolabeled Chemicals Inc, St Louis, MO, USA) as radioligands. Prefrontal cortex membranes from postmortem human brain were used as a source of receptors, given that $\mathrm{CB}_{1}$ receptors ${ }^{20}$ and $\mu$ opioid receptors are present in large amounts in this region. Neural membranes ( $\mathrm{P}_{2}$ fractions) were prepared from the prefrontal cortex of human brains obtained at autopsy (Instituto Vasco de Medicina Legal, Bilbao, Spain) as previously reported by our research group. ${ }^{16}$ These samples belong to the Brain Collection of the University of the Basque Country registered with the National Biobank Register of the
Spanish Health Department number (C 0000035). Specific $\left[{ }^{3} \mathrm{H}\right]$-CP55,940 or $\left[{ }^{3} \mathrm{H}\right]$-DAMGO binding was measured in $0.55 \mathrm{~mL}$ aliquots (50 mM Tris- $\mathrm{HCl}$ [Tris(hydroxymethyl) aminomethane hydrochloride], $\mathrm{pH}$ 7.5) of the neural membranes. The membranes were incubated with $\left[{ }^{3} \mathrm{H}\right]-$ CP55,940 (1 nM) for 60 minutes at $30^{\circ} \mathrm{C}$ or [ $\left.{ }^{3} \mathrm{H}\right]$-DAMGO $(2 \mathrm{nM})$ for 60 minutes at $25^{\circ} \mathrm{C}$ in the absence or presence of the competing compounds $\left(10^{-12} \mathrm{M}\right.$ to $10^{-3} \mathrm{M}$, ten concentrations). Incubations were terminated by diluting the samples with $5 \mathrm{~mL}$ of ice-cold Tris- $\mathrm{HCl}$ incubation buffer $\left(4^{\circ} \mathrm{C}\right)$. Membrane-bound radioligand was separated by vacuum filtration through Whatman $\mathrm{GF} / \mathrm{C}$ glass fiber filters (GE Healthcare, Buckinghamshire, UK). The filters were then rinsed twice with $5 \mathrm{~mL}$ of incubation buffer and transferred to mini-vials containing $3 \mathrm{~mL}$ of OptiPhase HiSafe ${ }^{\circledR}$ II cocktail (PerkinElmer) and counted for radioactivity by liquid scintillation spectrometry. Specific binding was determined and plotted as a function of the compound concentration. Nonspecific binding was determined in the presence of WIN 55,212-2 $\left(10^{-5} \mathrm{M}\right)$ or naloxone $\left(10^{-5} \mathrm{M}\right)$, respectively. Analysis of competition experiments to obtain the inhibition constant $\left(\mathrm{K}_{\mathrm{i}}\right)$ were performed by nonlinear regression using the GraphPad Prism program (GraphPad Software, Inc, San Diego, CA, USA). All experiments were analyzed assuming a one-site model of radioligand binding.

\section{$\mathrm{CB}_{2}$ binding evaluation}

$\mathrm{CB}_{2}$ receptor affinity was evaluated from membrane fractions of human embryonic kidney (HEK293 EBNA) cells transfected with human $\mathrm{CB}_{2}$ receptors (RBXCB2M400UA; Analytical Sciences, Boston, MA, USA). ${ }^{21}$ The $\mathrm{CB}_{2}$ receptor membrane protein concentration was $5.20 \mathrm{pmol} / \mathrm{mg}$ or $6.20 \mathrm{pmol} / \mathrm{mg}$ and the protein concentration was $4.0 \mathrm{mg} / \mathrm{mL}$ or $3.6 \mathrm{mg} / \mathrm{mL}$ depending on the batch. The commercial membranes were diluted (approximately 1:20) with the binding buffer $\left(50 \mathrm{mM}\right.$ Tris- $\mathrm{HCl}, 5 \mathrm{mM} \mathrm{MgCl} \cdot \mathrm{H}_{2} \mathrm{O}, 2.5 \mathrm{mM}$ ethylene glycol tetraacetic acid, $1 \mathrm{mg} / \mathrm{mL}$ bovine serum albumin, $\mathrm{pH}$ 7.5). The final membrane protein concentration was $0.2 \mathrm{mg} / \mathrm{mL}$ of incubation volume. The radioligand used was $\left[{ }^{3} \mathrm{H}\right]-\mathrm{CP} 55,940$ at a concentration of membrane $\mathrm{K}_{\mathrm{D}}$ (dissociation constant) $\times 0.8 \mathrm{~nm}$, and the final volume was $600 \mathrm{~mL}$. The 96-well plates and tubes necessary for the experiment were previously siliconized with Sigmacote (Sigma-Aldrich, St Louis, MO, USA). The membranes were resuspended in the corresponding buffer and were incubated with the radioligand and each compound $\left(10^{-4}-10^{-11} \mathrm{M}\right)$ for 90 minutes at $30^{\circ} \mathrm{C}$. Nonspecific binding was determined with $10 \mu \mathrm{M}$ WIN $55,212-2$, and $100 \%$ binding of the radioligand to the 
membrane was determined by its incubation with membrane without any compound. Filtration was performed by a Harvester ${ }^{\circledR}$ FilterMate (PerkinElmer) with Filtermat A $\mathrm{GF} / \mathrm{C}$ filters pretreated with polyethylenimine $0.05 \%$. After filtering, the filter was washed nine times with binding buffer, dried, and a melt-on scintillation sheet (MeltiLex ${ }^{\text {TM}}$; PerkinElmer) was melted onto it. Radioactivity was then quantified by a liquid scintillation spectrophotometer (Wallac MicroBeta ${ }^{\circledR}$ TriLux; PerkinElmer). Competition binding data were analyzed using the GraphPad Prism program, and $\mathrm{K}_{i}$ values are expressed as the mean \pm standard error of the mean (SEM) of at least three experiments performed in triplicate for each point.

\section{Functionality binding assays}

To determine the ability of the selected compounds to activate the $\mathrm{CB}_{1}$ and/or $\mu$ opioid receptors, $\left[{ }^{35} \mathrm{~S}\right]-\mathrm{GTP} \gamma \mathrm{S}$ (guanosine 5'-O-[gamma-thio]triphosphate) binding assays were performed in cortical membranes from post-mortem human brain. In this tissue, $\left[{ }^{35} \mathrm{~S}\right]-\mathrm{GTP} \gamma \mathrm{S}$ binds with high affinity to $\mathrm{G}_{\mathrm{i}} / \mathrm{G}_{\mathrm{o}}$ proteins. ${ }^{22}$ Thereby, agonists, inverse agonists, and antagonists can modulate this binding acting on a specific receptor, increasing (agonists) or decreasing (inverse agonists) the nucleotide binding or blocking the effect of an agonist (antagonists). The incubation buffer for measuring $\left[{ }^{35} \mathrm{~S}\right] \mathrm{GTP} \gamma \mathrm{S}$ binding to brain membranes contained $1 \mathrm{mM}$ ethylene glycol tetraacetic acid, $3 \mathrm{mM} \mathrm{MgCl}_{2}, 100 \mathrm{mM} \mathrm{NaCl}$, $50 \mathrm{mM}$ GDP (guanosine diphosphate), $50 \mathrm{mM}$ Tris- $\mathrm{HCl}$ at $\mathrm{pH} 7.4$, and $0.5 \mathrm{nM}\left[{ }^{35} \mathrm{~S}\right] \mathrm{GTP} \gamma \mathrm{S}$ (DuPont NEN, Brussels, Belgium) in a total volume of $500 \mu \mathrm{L}$. Protein aliquots were thawed and resuspended in the same buffer. The incubation was started by addition of the membrane suspension ( $40 \mu \mathrm{g}$ of membrane proteins) to the previous mixture and was performed at $30^{\circ} \mathrm{C}$ for 120 minutes with shaking. In order to evaluate the influence of the compounds on $\left[{ }^{35} \mathrm{~S}\right] \mathrm{GTP} \gamma \mathrm{S}$ binding, ten concentrations $\left(10^{-12}-10^{-3} \mathrm{M}\right)$ of the different compounds were added to the assay. Incubations were terminated by adding $3 \mathrm{~mL}$ of ice-cold resuspension buffer followed by rapid filtration through Whatman GF/C filters presoaked in the same buffer. The filters were rinsed twice with $3 \mathrm{~mL}$ of ice-cold resuspension buffer, transferred to vials containing $5 \mathrm{~mL}$ of OptiPhase HiSafe II cocktail, and the radioactivity trapped was determined by liquid scintillation spectrometry (Packard 2200CA; Packard Instrument Company, Meriden, CT, USA). The $\left[{ }^{35} \mathrm{~S}\right] \mathrm{GTP} \gamma \mathrm{S}$ bound was about $7 \%-14 \%$ of the total $\left[{ }^{35} \mathrm{~S}\right] \mathrm{GTP} \gamma \mathrm{S}$ added. Nonspecific binding of the radioligand was defined as the remaining $\left[{ }^{35} \mathrm{~S}\right] \mathrm{GTP} \gamma \mathrm{S}$ binding in the presence of $10 \mu \mathrm{M}$ unlabeled GTP $\gamma \mathrm{S}$.

\section{In vivo cannabinoid tetrad assays}

Male imprinting control region mice weighing 25-30 g were used. Spontaneous behavior was always observed in the cage before treatment and/or performance of the different tests. Animals showing spontaneous behavioral modifications were discarded. To evaluate agonist effects, reference drugs and new compounds were administered 15 minutes (for the cannabinoid tetrad) and 30 minutes (for the opioid hot plate test) before starting the behavioral tests. When the compounds were tested as antagonists, they were administered 20 minutes before the reference agonists (WIN 55,212-2 or morphine). All drugs were given intraperitoneally. Separate groups of mice ( $\mathrm{n}=8-10$ each) were given the following treatments: saline solution or vehicle (controls); WIN 55,212-2 $1.5 \mathrm{mg} / \mathrm{kg}$; $4 \mathrm{~d} 10 \mathrm{mg} / \mathrm{kg}$; 4e $5 \mathrm{mg} / \mathrm{kg}$; rimonabant $1 \mathrm{mg} / \mathrm{kg}$; rimonabant $1 \mathrm{mg} / \mathrm{kg}+$ WIN 55,212-2 $1.5 \mathrm{mg} / \mathrm{kg}$; $4 \mathrm{~d} 2 \mathrm{mg} / \mathrm{kg}+$ WIN 55,212-2 $1.5 \mathrm{mg} / \mathrm{kg} ; 4 \mathrm{~d} 4 \mathrm{mg} / \mathrm{kg}+\mathrm{WIN}$ $55,212-21.5 \mathrm{mg} / \mathrm{kg}$; $4 \mathrm{~d} 8 \mathrm{mg} / \mathrm{kg}+$ WIN 55,212-2 $1.5 \mathrm{mg} / \mathrm{kg}$; and $4 \mathrm{e} 5 \mathrm{mg} / \mathrm{kg}+\mathrm{WIN} \mathrm{55,212-2} 1.5 \mathrm{mg} / \mathrm{kg}$. The tests were conducted consecutively at 5-minute intervals.

\section{Hypothermia}

Core mouse temperatures were measured using a lubricated thermometer inserted into the rectum to a constant depth of $1 \mathrm{~cm}$. Temperature was evaluated twice in each animal, ie, before and after every treatment.

\section{Locomotor activity}

Spontaneous locomotor activity was evaluated using individual photocell activity chambers $\left(\right.$ Cibertec $^{\circledR}$, San Jose, Costa Rica). The mouse was placed in a chamber and, starting 10 minutes later, the number of interruptions of photocell beams was recorded over a 30-minute period. The mean number of crossings was compared with that obtained from a mouse control group that had received vehicle.

\section{Nociception}

The hot plate test was carried out using a hot plate at $55^{\circ} \mathrm{C}$ as the nociceptive stimulus. The latency time of licking of the front paw was taken as an index of nociception. The latency was measured before treatment (control latency) and after every treatment (latency after treatment). The cut-off time was 30 seconds and analgesia was quantified with the formula of the maximum possible effect (MPE), expressed as a percentage:

$\% \mathrm{MPE}=($ Latency after treatment - Control latency $) /$

(Cut-off time - Control latency) $\times 100$ 


\section{Catalepsy}

Catalepsy was measured using a modified "ring test" as originally described by Pertwee. ${ }^{23}$ The mice were placed on a rubber-coated metal ring ( $6 \mathrm{~cm}$ in diameter) fixed horizontally at a height of $30 \mathrm{~cm} . \mathrm{CB}_{1}$ cannabinoid agonists cause animals to become cataleptic, and the sum of all times during which the mice were immobile was registered for a 5-minute period and compared with the time registered in control animals. The criterion for immobility was the absence of all voluntary movement.

To confirm the duration of the effect of the new compounds, they were tested as antagonists on the hot plate test. Next, $4 \mathrm{~d}(4 \mathrm{mg} / \mathrm{kg}$, intraperitoneally) and $4 \mathrm{e}(5 \mathrm{mg} / \mathrm{kg}$ intraperitoneally) were administered 20 minutes before WIN $55,212-2(1.5 \mathrm{mg} / \mathrm{kg}$ intraperitoneally) and the test was performed 1 hour after injection of this agonist.

\section{In vivo opioid response on hot plate test}

To assess the opioid activity of the new compounds $4 \mathrm{~d}$ and $4 \mathrm{e}$, the hot plate test was carried out as described above and separate groups of mice $(\mathrm{n}=8-10$ each) were treated with: saline solution or vehicle (controls); $4 \mathrm{~d} 10 \mathrm{mg} / \mathrm{kg} ; 4 \mathrm{e}$ $10 \mathrm{mg} / \mathrm{kg}$; naloxone $1 \mathrm{mg} / \mathrm{kg}$; rimonabant $1 \mathrm{mg} / \mathrm{kg}$; morphine $10 \mathrm{mg} / \mathrm{kg}$; $4 \mathrm{~d} 10 \mathrm{mg} / \mathrm{kg}$ + morphine $10 \mathrm{mg} / \mathrm{kg}$; $4 \mathrm{e}$ $10 \mathrm{mg} / \mathrm{kg}+$ morphine $10 \mathrm{mg} / \mathrm{kg}$; naloxone $1 \mathrm{mg} / \mathrm{kg}+$ morphine $10 \mathrm{mg} / \mathrm{kg}$; and rimonabant $1 \mathrm{mg} / \mathrm{kg}$ + morphine $10 \mathrm{mg} / \mathrm{kg}$. The data are expressed as the mean \pm SEM. For the in vitro assays, values for $\mathrm{EC}_{50}$ (half-maximal effective concentration) and $95 \%$ confidence limits of these values for agonists were calculated by nonlinear regression analysis using the equation for a sigmoid concentration-response curve (GraphPad Prism). For the effects of drugs on in vitro and in vivo tests, a one-way analysis of variance was used for statistical analysis of multiple comparisons within each group. When a significant difference was detected by one-way analysis of variance, the data were further analyzed using Newman-Keuls test. In each test, a $P$-value less than 0.05 was considered to indicate statistical significance. Drugs (WIN 55,212-2 mesylate and rimonabant) were obtained from Tocris (Biogen Científica SL, Madrid, Spain) and Sanofi, respectively. DAMGO, DL-dithiothreitol, GDP, GTP, GTP $\gamma$ S, fentanyl, and naloxone were purchased from Sigma-Aldrich. Morphine $\mathrm{HCl}$ was obtained from Alcaliber SA (Madrid, Spain). Morphine sulfate salt solution and naloxone hydrochloride dihydrate were obtained from Sigma-Aldrich (Madrid, Spain). All other chemicals were of the highest commercially available purity. Cannabinoids were dissolved in ethanol $1 \mathrm{mg}: 1 \mathrm{~mL}$ and subsequently in ethanol and Tween 80 (1:2), after which the ethanol was evaporated. Other drugs were dissolved in saline solution $(0.9 \%)$.

\section{Alcohol intake assays}

The operant ethanol self-administration was examined following a protocol essentially based on a previously published alcohol relapse model in Wistar rats. ${ }^{24}$

\section{Administration, distribution, metabolism, excretion (ADME) properties in silico}

ADME properties were calculated using QikProp version 3.5 integrated in Maestro (Schrödinger, LLC, New York, NY, USA). The global minimum energy conformer used as input was generated using the program Spartan '08 (Wave Function, Inc, Irvine, CA, USA). Ab initio energy minimizations were performed at the Hartree-Fock 6-31G* level.

\section{Results and discussion Receptor affinities and structure- activity relationship}

Concerning the $\mathrm{CB}_{1}$ cannabinoid binding, Table 1 displays the $\mathrm{K}_{\mathrm{i}}$ values obtained for $4 \mathrm{a}-4 \mathrm{k}$ and for AM251 (Tocris, Bristol, $\mathrm{UK}$ ) and rimonabant as reference $\mathrm{CB}_{1}$ ligands. Some of the new compounds (4a, 4b, 4d-4f, 4k) showed low to medium affinity $\left(\mathrm{K}_{i}=0.19-3.99 \mu \mathrm{M}\right)$, while others $(4 \mathrm{c}$, $4 \mathrm{~g}-4 \mathrm{j}$ ) did not show any affinity for the $\mathrm{CB}_{1}$ receptor in this assay $\left(\mathrm{K}_{i}>10 \mu \mathrm{M}\right)$. The ligands showing the highest affinity were compounds $4 \mathrm{~b}\left(\mathrm{~K}_{i}=0.57 \mu \mathrm{M}\right)$, and $4 \mathrm{e}\left(\mathrm{K}_{i}=0.70 \mu \mathrm{M}\right)$, containing a butyl and a heptyl chain linker, respectively. Now, if we refer to our recent published binding data on bivalent cannabinoid ligands ${ }^{25}$ (Figure 2), it is interesting to note that the bivalent molecule with the heptyl linker also showed the best $\mathrm{CB}_{1}$ affinity. Actually, the alkyl chain length does not correlate with $\mathrm{CB}_{1}$ receptor affinity. However, the values obtained for $4 \mathrm{~g}-4 \mathrm{j}$ indicate that aromatic spacers and longer alkyl chains lead to a loss of $\mathrm{CB}_{1}$ cannabinoid receptor affinity. Interestingly, replacing the linear alkyl chain of nine methylene units $\left(4 \mathrm{~g} ; \mathrm{K}_{i}>10 \mu \mathrm{M}\right)$ with a biscyclohexylene $\left(4 \mathrm{k} ; \mathrm{K}_{i}=2.06 \mu \mathrm{M}\right)$ as a conformation constrainer, resulted in increased affinity for the $\mathrm{CB}_{1}$ receptor.

The $\mu$ opioid binding component is reflected in Table 1. Excluding 4a, 4e, and 4h, which showed a $\mathrm{K}_{i}$ higher than $3.8 \mu \mathrm{M}$, the $\mathrm{K}_{i}$ values of $4 \mathrm{~b}-\mathrm{d}, 4 \mathrm{f}-\mathrm{g}$, and $4 \mathrm{i}-\mathrm{k}$, that ranged from $205 \mathrm{nM}$ to $1.3 \mu \mathrm{M}$, indicate moderate affinity for the $\mu$ opioid receptor. Compounds $4 \mathrm{~g}, 4 \mathrm{c}$, and $4 \mathrm{~d}$ showed the best $\mathrm{K}_{i}$ values $(108,166$, and $295 \mathrm{nM}$, respectively). 


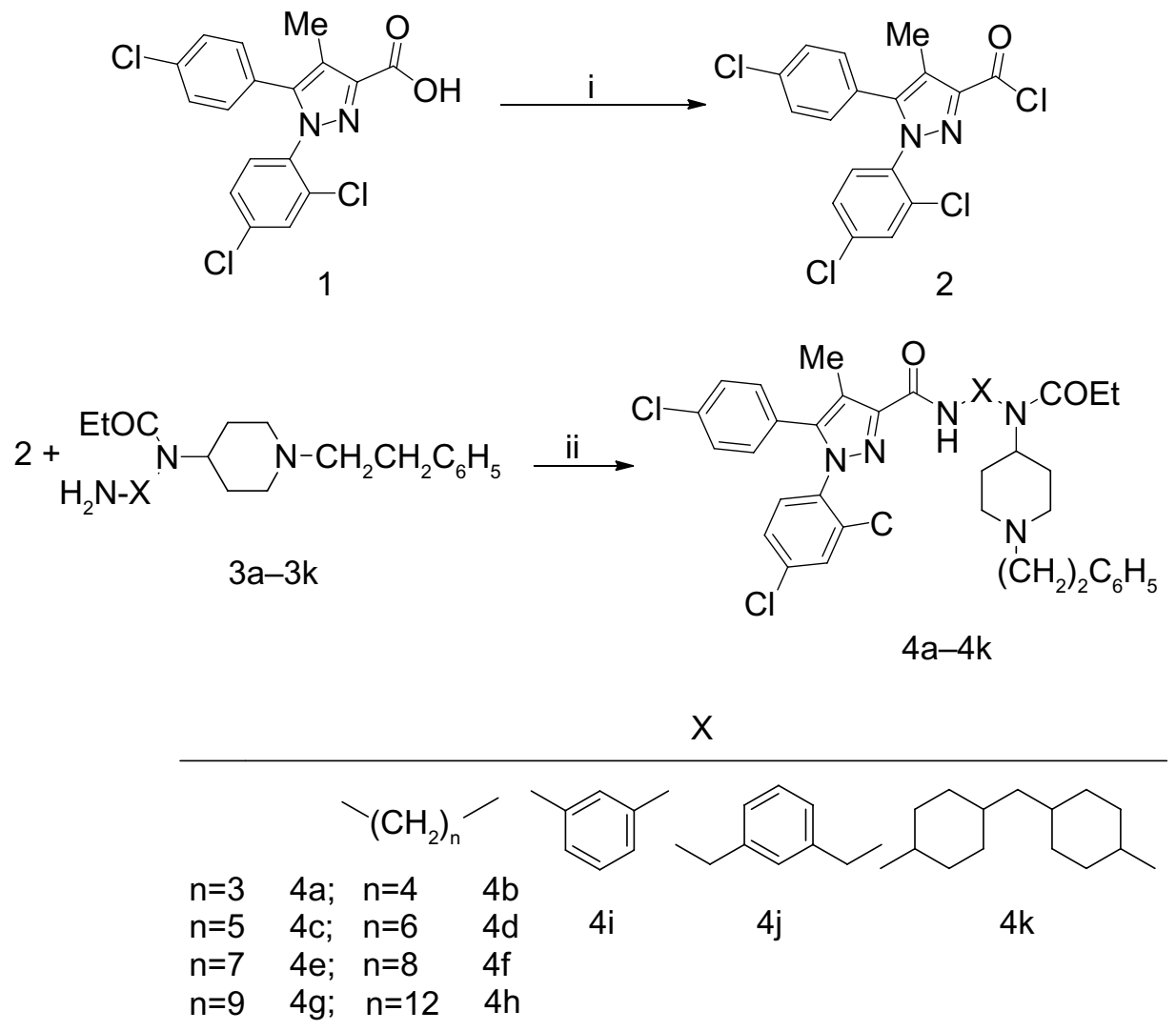

Figure 3 Synthesis of the pyrazole carboxamide derivatives $4 \mathrm{a}-4 \mathrm{k}$. Reagents and conditions: (i) $\mathrm{SOCl}_{2}$, toluene, $\Delta$ (reflex temperature); (ii) $\mathrm{CH}_{2} \mathrm{Cl}_{2}$, Et ${ }_{3} \mathrm{~N}$, room temperature.

These $\mathrm{CB}_{1}$ and opioid competitive displacement assays were performed in the post-mortem human brain, where $\mathrm{CB}_{1}$ and opioid receptors are present in large amounts and where the presence of dimers and heteromers has been proposed.

Table I Binding affinity of compounds $4 a-4 k$ for $C_{1}$ cannabinoid and $\mu$ opioid receptors

\begin{tabular}{|c|c|c|c|}
\hline Compound & $x$ & $\begin{array}{l}\left.{ }^{3} \mathrm{H}\right]-C P 55,940 \\
C B_{1} K_{i}(\mu M)^{a}\end{array}$ & $\begin{array}{l}\left.{ }^{3} \mathrm{H}\right] \text {-DAMGO } \\
\mu \mathrm{K}_{\mathrm{i}}(\mu \mathrm{M})^{\mathrm{a}}\end{array}$ \\
\hline AM25I & & $0.005 \pm 0.002$ & ND \\
\hline Rimonabant & & $0.004 \pm 0.002$ & $0.20 \pm 0.12$ \\
\hline Fentanyl & & ND & $0.003 \pm 0.001$ \\
\hline $4 a$ & $-\left(\mathrm{CH}_{2}\right)_{3}-$ & $0.19 \pm 0.07$ & $3.8 I \pm 0.39$ \\
\hline $4 b$ & $-\left(\mathrm{CH}_{2}\right)_{4}-$ & $0.57 \pm 0.20$ & $1.23 \pm 0.43$ \\
\hline $4 c$ & $-\left(\mathrm{CH}_{2}\right)_{5}-$ & $>10$ & $0.17 \pm 0.10$ \\
\hline $4 d$ & $-\left(\mathrm{CH}_{2}\right)_{6}-$ & $2.29 \pm 1.86$ & $0.30 \pm 0.06$ \\
\hline $4 e$ & $-\left(\mathrm{CH}_{2}\right)_{7}-$ & $0.70 \pm 0.57$ & $6.54 \pm 0.95$ \\
\hline $4 f$ & $-\left(\mathrm{CH}_{2}\right)_{8}-$ & $3.99 \pm 1.37$ & I. $24 \pm 0.79$ \\
\hline $4 g$ & $-\left(\mathrm{CH}_{2}\right)_{9}-$ & $>10$ & $0.11 \pm 0.06$ \\
\hline $4 h$ & $-\left(\mathrm{CH}_{2}\right)_{12}-$ & $>10$ & $6.90 \pm 1.58$ \\
\hline $4 i$ & & $>10$ & $1.25 \pm 0.67$ \\
\hline $4 j$ & & $>10$ & $1.02 \pm 0.25$ \\
\hline $4 k$ & & $2.06 \pm 0.60$ & $0.66 \pm 0.37$ \\
\hline
\end{tabular}

Notes: ${ }^{a}$ Values are expressed as the mean \pm SEM of at least three experiments. Rimonabant (Sanofi, Paris, France); Fentanyl. ${ }^{13}$

Abbreviations: ND, not determined; SEM, standard error of the mean; DAMGO, [D-Ala $\left.{ }^{2}, \mathrm{~N}-\mathrm{MePhe}^{4}, \mathrm{Gly}-\mathrm{ol}\right]$-enkephalin.
The fact that the new compounds with affinity for both receptors have the shortest linkers suggests that they bind to $\mathrm{CB}_{1}$ and to opioid monomers. Spacers ranging from 10 to 20 atoms are necessary for the molecule to bridge heteromer receptors. It is unlikely that these hybrid molecules target a $\mathrm{CB}_{1}$ opioid heteromer. However, they bind individually to the respective receptors. Regarding $\mathrm{CB}_{2}$ receptor binding assays, compounds $4 \mathrm{a}-4 \mathrm{j}$ did not show any significant affinity $(>40 \mu \mathrm{M})$, thus indicating $\mathrm{CB}_{1}$ selectivity. $\mathrm{CB}_{2}$ binding assay for $4 \mathrm{k}$ could not be carried out for solubility reasons. The new compounds have a $\mathrm{CB}_{1}$ activity profile.

\section{Functionality}

Although these new compounds showed modest affinity, evaluation of their functionality has yielded interesting results. We selected $4 \mathrm{~b}$ and $4 \mathrm{e}$ for their $\mathrm{CB}_{1}$ cannabinoid affinity and $4 \mathrm{~d}$ for its $\mu$ opioid affinity along with a micromolar $\mathrm{CB}_{1}$ affinity constant value. $\left[{ }^{35} \mathrm{~S}\right]-\mathrm{GTP} \gamma \mathrm{S}$ binding assays have been performed in cortical membranes from the post-mortem human brain to determine the ability of the selected compounds to activate the $\mathrm{CB}_{1}$ and/or $\mu$ opioid receptors.

We first evaluated the direct effect of compounds $4 \mathrm{~b}, 4 \mathrm{~d}$, and $4 \mathrm{e}$. Compound $4 \mathrm{~b}$ produced an inhibition of basal $\left[{ }^{35} \mathrm{~S}\right]-$ GTP $\gamma$ S binding $\left(\mathrm{EC}_{50} 25 \pm 4 \mu \mathrm{M}\right.$; Figure 4), demonstrating its 
inverse agonist effect. This effect is similar to that induced by the well known $\mathrm{CB}_{1}$ inverse agonist/antagonist rimonabant, used as reference $\left(\mathrm{EC}_{50} 19 \pm 4 \mu \mathrm{M}\right.$; Figure 4$) .{ }^{26}$ Compounds $4 \mathrm{~d}, 4 \mathrm{e}$, and the opioid-selective antagonist naloxone did not induce any significant change in basal $\left.{ }^{35} \mathrm{~S}\right]-\mathrm{GTP} \gamma \mathrm{S}$ binding values, indicating a lack of agonist or inverse agonist properties (Figure 4).

The next step was to characterize their antagonist effect on cannabinoid receptors. The maximum agonist effects $\left(\mathrm{E}_{\max }\right)$ of WIN 55,212-2 ( $\left.\mathrm{E}_{\max } 184 \% \pm 4 \% ; \mathrm{EC}_{50} 1.1 \pm 0.22 \mu \mathrm{M}\right)$ were reverted by each of the new compounds ( $4 \mathrm{~b}, 4 \mathrm{~d}$, and $4 \mathrm{e}$ ), as well as by rimonabant, at a single concentration $\left(10^{-5} \mathrm{M}\right.$, Figure 5A). They produced a rightward displacement of the WIN 55,212-2 dose-response curve $\left(\mathrm{EC}_{50}\right.$ for rimonabant, $21 \pm 3 \mu \mathrm{M} ; \mathrm{EC}_{50}$ for $4 \mathrm{~b}, 33 \pm 8 \mu \mathrm{M} ; \mathrm{EC}_{50}$ for $4 \mathrm{~d}, 21 \pm 2 \mu \mathrm{M}$; $\mathrm{EC}_{50}$ for $\left.4 \mathrm{e}, 16 \pm 2 \mu \mathrm{M}\right)$. These data show that $4 \mathrm{~b}, 4 \mathrm{~d}$, and $4 \mathrm{e}$ behave as antagonists of the $\mathrm{CB}_{1}$ cannabinoid receptor with potency similar to that of rimonabant. Conversely, the opioid antagonist naloxone $\left(10^{-5} \mathrm{M}\right)$ did not change the WIN 55,212-2 stimulation $\left(\mathrm{EC}_{50} 1.3 \pm 0.17 \mu \mathrm{M} ; \mathrm{E}_{\max } 187 \% \pm 4 \%\right.$ ).

Finally, compounds $4 \mathrm{~b}, 4 \mathrm{~d}$, and $4 \mathrm{e}$ have been evaluated for their antagonism at the $\mu$ opioid receptor. The agonist effects of the opioid fentanyl $\left(\mathrm{E}_{\max } 146 \% \pm 2 \% ; \mathrm{EC}_{50}\right.$ $0.28 \pm 0.04 \mu \mathrm{M}$ ) were blocked by $4 \mathrm{~b}, 4 \mathrm{~d}, 4 \mathrm{e}$, and naloxone at a single concentration $\left(10^{-5} \mathrm{M}\right.$, Figure $\left.5 \mathrm{~B}\right)$. All of these caused a rightward displacement of the fentanyl dose-response $\left(\mathrm{EC}_{50}=456 \pm 60 \mu \mathrm{M}\right.$ for naloxone; $\mathrm{EC}_{50}=24 \pm 5 \mu \mathrm{M}$ for $4 \mathrm{~b}$; $\mathrm{EC}_{50}=33 \pm 2 \mu \mathrm{M}$ for $4 \mathrm{~d} ; \mathrm{EC}_{50}=3 \pm 1 \mu \mathrm{M}$ for $4 \mathrm{e}$ ). These data confirm that $4 \mathrm{~b}, 4 \mathrm{~d}$, and $4 \mathrm{e}$ behave as opioid antagonists.

With the above functionality studies, we clearly demonstrate that $4 \mathrm{~b}, 4 \mathrm{~d}$, and $4 \mathrm{e}$ have dual functionality, ie,
$\mathrm{CB}_{1}$ receptor antagonism with potency similar to that of rimonabant and $\mu$ opioid receptor antagonism with potency superior to that of naloxone. Since previous studies suggested therapeutic interest in coadministration of a cannabinoid antagonist and an opioid antagonist, ${ }^{27-30}$ we considered that it would be interesting to follow on with in vivo studies.

\section{Behavioral properties}

The in vivo cannabinoid properties of $4 \mathrm{~d}$ and $4 \mathrm{e}$ were characterized on the basis of their behavioral effects in mice. Cannabinoid agonists have been shown to induce a drop in body temperature, catalepsy on an elevated ring, acute analgesia on a hot plate, and a decrease of spontaneous activity in an open field. ${ }^{31}$ Compound $4 \mathrm{~d}$, at the three tested doses (intraperitoneal administration; Figure 6) antagonized all the effects produced by the cannabinoid agonist WIN $55,212-2(1.5 \mathrm{mg} / \mathrm{kg})$, the difference being statistically significant for rectal temperature, catalepsy, and analgesia. Three (catalepsy, analgesia, and reduction of the spontaneous activity) of the four effects induced by WIN 55,212-2 $(1.5 \mathrm{mg} / \mathrm{kg})$ on mice were significantly prevented by $4 \mathrm{e}$ $(5 \mathrm{mg} / \mathrm{kg}$, intraperitoneal administration; Figure 7). These results support the antagonistic $\mathrm{CB}_{1}$ cannabinoid properties of $4 \mathrm{~d}$ and $4 \mathrm{e}$. It is unlikely that this antagonism could be due to loss of $\mathrm{CB}_{1}$ receptors as a consequence of a downregulation process since it is normally the result of chronic rather than acute administration, as in this case.

To assess the duration of effect of $4 \mathrm{~d}$ and $4 \mathrm{e}$, the hot plate test was carried out after intraperitoneal injection of WIN $55,212-2(1.5 \mathrm{mg} / \mathrm{kg}$ ). Both compounds ( $4 \mathrm{~d}$ at $4 \mathrm{mg} / \mathrm{kg}$ and $4 \mathrm{e}$ at $5 \mathrm{mg} / \mathrm{kg}$, administered intraperitoneally) completely

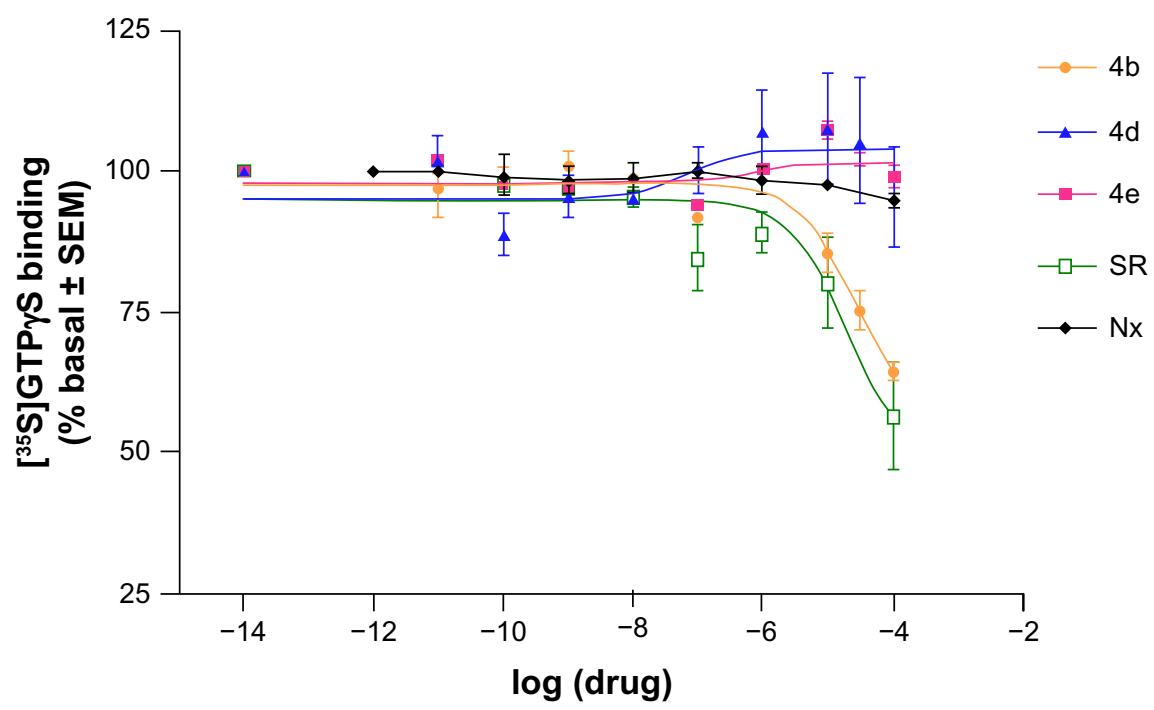

Figure 4 Concentration-response curves for stimulation of $\left[{ }^{35} \mathrm{~S}\right]-\mathrm{GTP} \gamma \mathrm{S}$ binding by $4 \mathrm{~b}, 4 \mathrm{~d}, 4 \mathrm{e}$, rimonabant, and naloxone to cortical membranes in the post-mortem human brain. The data are expressed as the mean ( \pm SEM) values for 4-6 experiments performed in different brain samples.

Notes: Rimonabant (Sanofi, Paris, France); naloxone (Sigma-Aldrich, Madrid, Spain).

Abbreviations: SR, rimonabant; Nx, naloxone; SEM, standard error of the mean; GTP $\gamma$, guanosine 5'-O-[gamma-thio]triphosphate. 

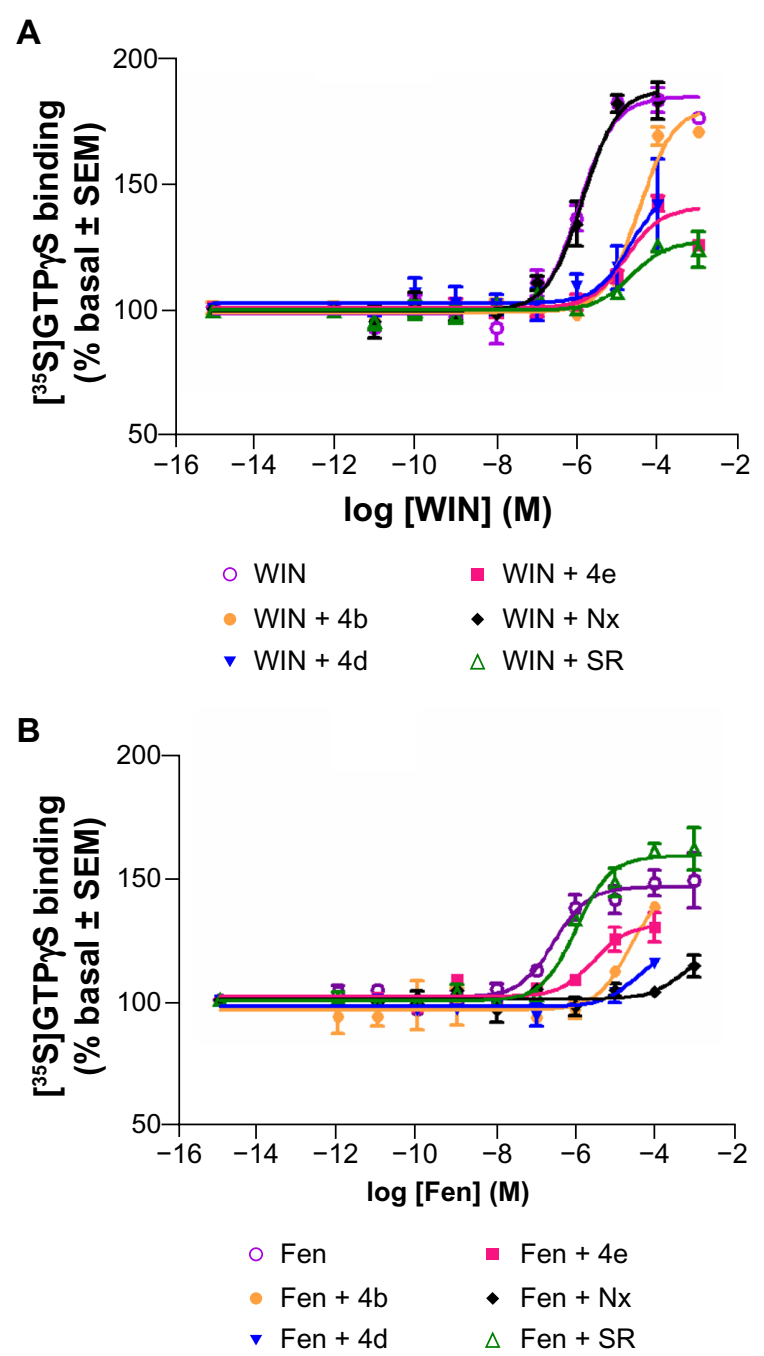

Figure 5 Concentration-response curves for stimulation of $\left.{ }^{35} \mathrm{~S}\right]-\mathrm{GTP} \gamma \mathrm{S}$ binding by WIN 55,2I 2-2 (Tocris/Biogen Científica SL, Madrid, Spain) (A) or fentanyl (B) in the absence $(\circ)$ or presence of a single concentration $\left(10^{-5} \mathrm{M}\right)$ of $4 \mathrm{~b}, 4 \mathrm{e}, 4 \mathrm{~d}$, naloxone, or rimonabant. The experiments were performed using cortical membranes in the post-mortem human brain. The data are expressed as the mean \pm SEM values from 4-8 experiments carried out in different brain samples.

Abbreviations: SR, rimonabant; Nx, naloxone; WIN, WIN 55,212-2; Fen, fentanyl; SEM, standard error of the mean; GTP $\gamma$ S, guanosine 5'-O-[gamma-thio] triphosphate.

and significantly $(P<0.001$, one-way analysis of variance $)$ reversed the effect of the cannabinoid agonist WIN 55,212-2 (percent of MPE for $4 \mathrm{~d}=3.5 \pm 2.5$ and percent MPE for $4 \mathrm{e}=5.7 \pm 4.7$; values shown as the mean \pm SEM $[n=6]$ ).

The in vivo opioid properties of $4 \mathrm{~d}$ and $4 \mathrm{e}$ were evaluated using a hot plate test at $55^{\circ} \mathrm{C}$ as the nociceptive stimulus (Figure 8). Treatment with the $\mu$ opioid agonist morphine induced antinociception that was reversed by the opioid antagonist naloxone but not by the cannabinoid antagonist rimonabant. The data described above show that intraperitoneal administration of $4 \mathrm{~d}(10 \mathrm{mg} / \mathrm{kg})$ or $4 \mathrm{e}(10 \mathrm{mg} / \mathrm{kg})$ did not induce any analgesic effect. However, when $4 \mathrm{~d}(10 \mathrm{mg} / \mathrm{kg}$, intraperitoneally) or $4 \mathrm{e}(10 \mathrm{mg} / \mathrm{kg}$, intraperitoneally) were administered 20 minutes before injection of morphine
$(10 \mathrm{mg} / \mathrm{kg})$, the antinociceptive effect of morphine was partially antagonized. This effect reached statistical significance in the case of $4 \mathrm{e}$. From these findings, it can be concluded that $4 \mathrm{~d}$ and $4 \mathrm{e}$ exhibit a $\mu$ opioid antagonist profile.

An extensive literature search suggests that the endocannabinoid and $\mu$ opioid systems are involved in the development of alcohol dependence. In rodent models, rimonabant was found to decrease alcohol consumption. ${ }^{24}$ Treatment with the nonselective opioid antagonist naltrexone was effective in modulating aspects of alcohol-seeking behavior. ${ }^{32}$ Due to the $\mu$ opioid and $\mathrm{CB}_{1}$ cannabinoid dual antagonist activity on behavioral evaluations of $4 \mathrm{e}$, the effects of this compound on operant ethanol self-administration were examined following a protocol essentially based on the alcohol relapse model in Wistar rats. For this purpose, the alcohol deprivation effect model previously reported by our group was used..$^{33}$ The animals did not show significant changes in number of alcohol responses compared with the vehicle group during treatment with $4 \mathrm{e}$ at doses of $0.5 \mathrm{mg} / \mathrm{kg}, 2.0 \mathrm{mg} / \mathrm{kg}$, and $8.0 \mathrm{mg} / \mathrm{kg}$ (data not shown).

\section{ADME parameters in silico}

A computational approach is considered to be an appropriate tool in early-stage drug discovery. Therefore, in silico ADME predictions can provide significant insights into drug-like properties.$^{34}$ Calculation of ADME properties of $4 \mathrm{e}$ was performed on the conformer of global minimum energy using QikProp version 3.5 integrated in Maestro with a set of 34 physicochemical descriptors. Based on our predicted data, Lipinski ${ }^{35}$ and Jorgensen ${ }^{36}$ pharmacokinetic rules are followed. With regard to blood-brain barrier penetration ( $\log \mathrm{BB}-0.8 ;-3.0 / 1.2$ for $95 \%$ of drugs), compound $4 \mathrm{e}$ was predicted to penetrate the brain. This prediction is consistent with its high lipophilicity $(\log \mathrm{P}[$ octanol/water $]=9.9)$, and with the results obtained in the in vivo assays. As expected, compound $4 \mathrm{e}$ is poorly water-soluble $(\log \mathrm{S}-12.6 ;-6.5 / 0.5$ for $95 \%$ of drugs). However, the predicted human oral absorption is good (100\%). Finally, in silico studies indicate unfavorable hERG (human Ether-à-go-go Related Gene) $\mathrm{K}+$ channel blockade, with a $\log \mathrm{IC}_{50}$ (inhibitory concentration 50) of -9.671 (range $95 \%$ of drugs; $\log \mathrm{IC}_{50}<-5$ ). This in silico approach suggests that $4 \mathrm{e}$ has an acceptable ADME and cardiotoxicity profile.

\section{Conclusion}

Using the $\mathrm{CB}_{1}$ cannabinoid receptor inverse agonist/ antagonist rimonabant (SR141716) as a scaffold, a series of pyrazole carboxamides containing part of the opioid fentanyl structure were prepared $(4 \mathrm{a}-4 \mathrm{k})$. The structural 

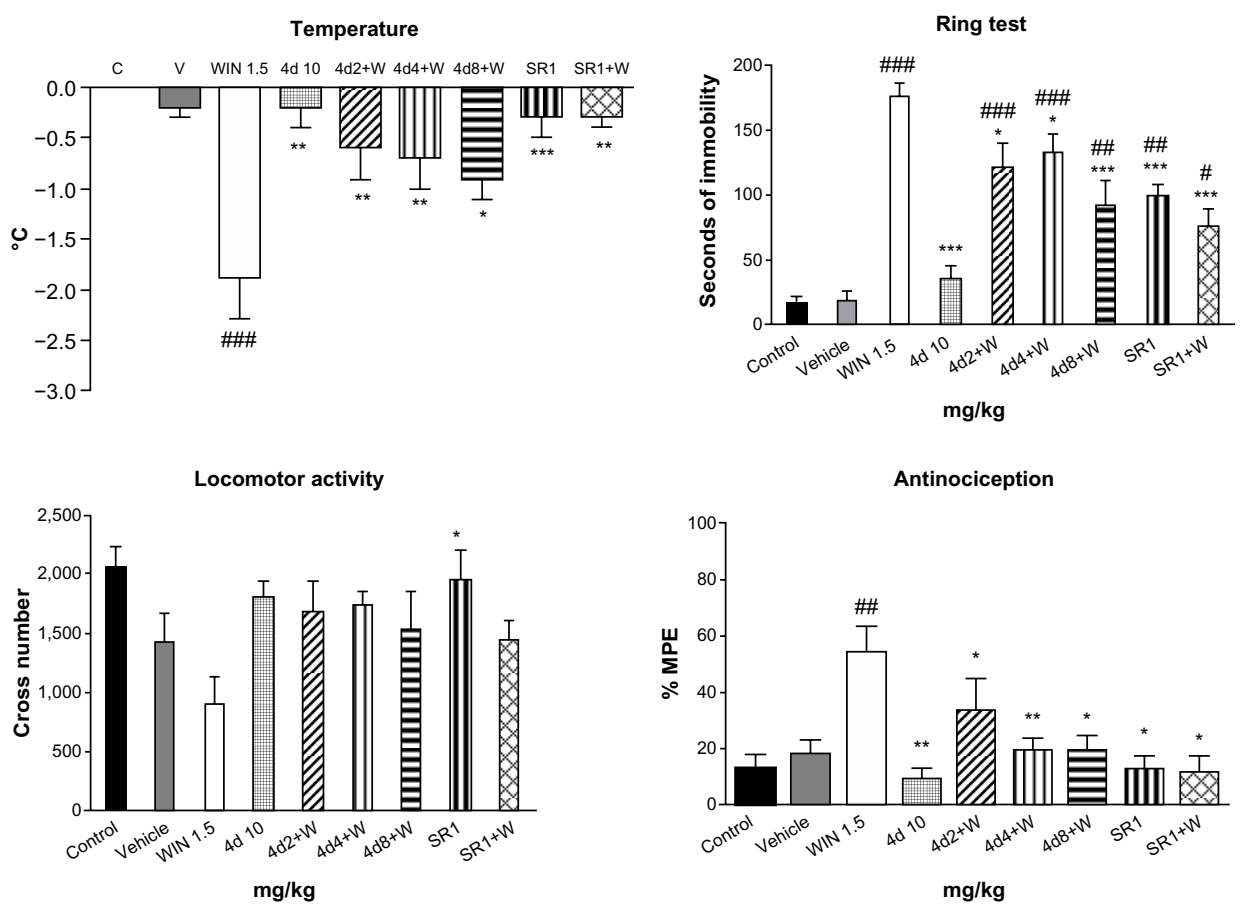

Figure 6 Effects of $4 \mathrm{~d}$ on the cannabinoid tetrad. Bars show modifications induced by treatment with WIN 55,212-2 $1.5 \mathrm{mg} / \mathrm{kg}, 4 \mathrm{~d} 10 \mathrm{mg} / \mathrm{kg}$, rimonabant I mg/kg, and WIN $55,212-21.5 \mathrm{mg} / \mathrm{kg}$ after treatment with rimonabant I mg/ $/ \mathrm{kg}$ or $4 \mathrm{~d} \mathrm{2}$, 4, or $8 \mathrm{mg} / \mathrm{kg}$. ${ }^{\circ} \mathrm{C}$ represents body temperature; Seconds of immobility represents catalepsy on an elevated ring; Cross number represents the number of interruptions of photocell beams.

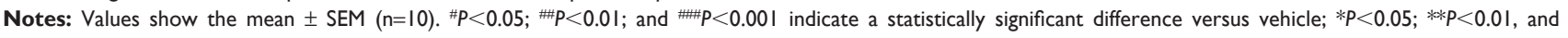
$* * * P<0.00$ I indicate a statistically significant difference versus WIN (one-way analysis of variance, Newman-Keuls post hoc test). WIN55,2I2-2 (Tocris/Biogen Científica SL, Madrid, Spain).

Abbreviations: W, WIN 55,2I2-2; SR, rimonabant; SEM, standard error of the mean; MPE, maximum possible effect; C, control; V, vehicle.
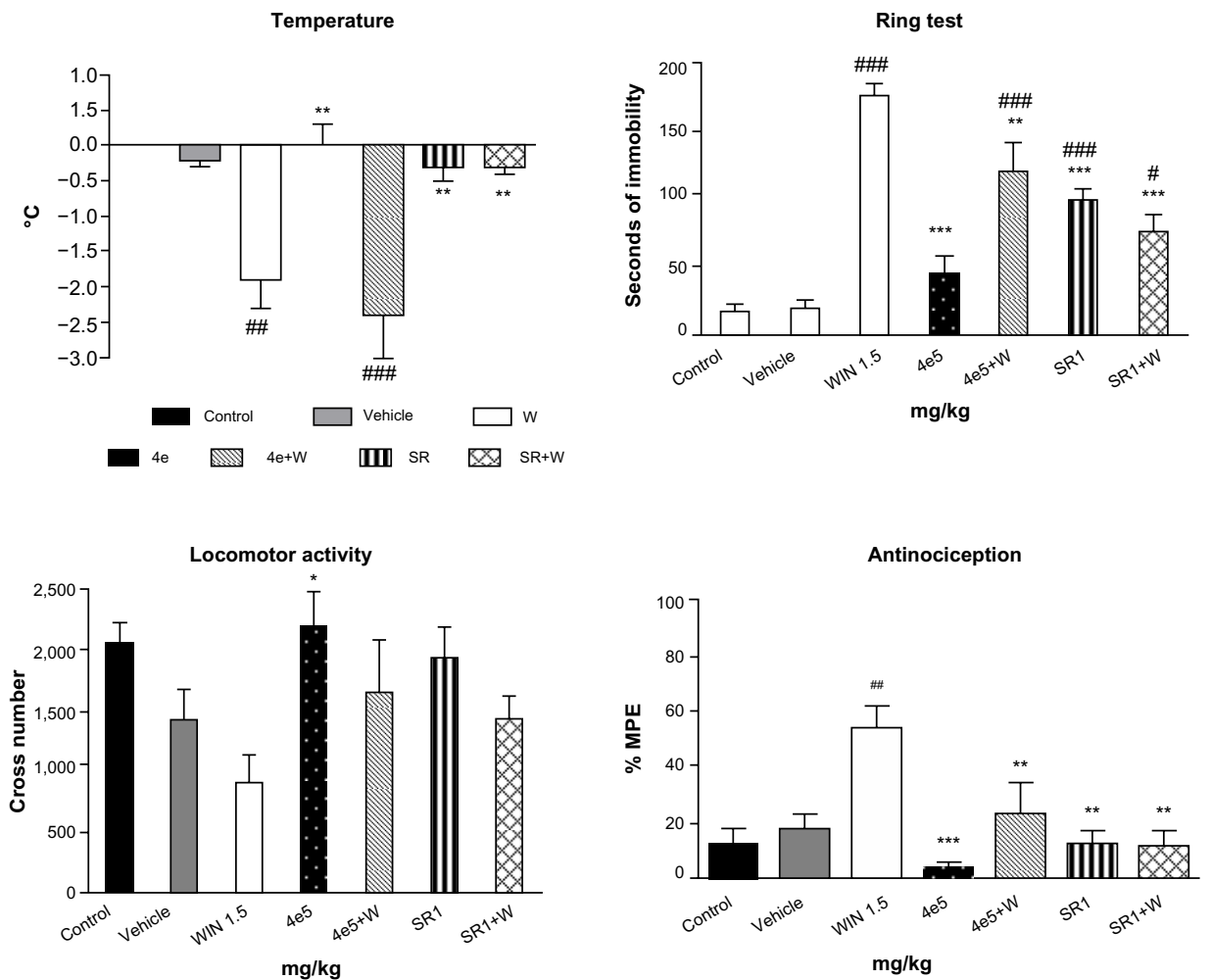

Figure 7 Effects of $4 \mathrm{e}$ on the cannabinoid tetrad. Bars show modifications induced by treatment with WIN 55,2I $2-21.5 \mathrm{mg} / \mathrm{kg}, 4 \mathrm{e} 5 \mathrm{mg} / \mathrm{kg}$, rimonabant I mg/kg, and WIN $55,212-21.5 \mathrm{mg} / \mathrm{kg}$ after treatment with rimonabant I mg/kg or $4 \mathrm{e} 5 \mathrm{mg} / \mathrm{kg}$. ${ }^{\circ} \mathrm{C}$ represents body temperature; Seconds of immobility represents catalepsy on an elevated ring; Cross number represents the number of interruptions of photocell beams.

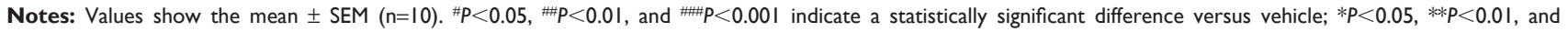
${ }^{*} * * P<0.001$ indicate a statistically significant difference versus WIN (one-way analysis of variance, Newman-Keuls post hoc test). Rimonabant (Sanofi, Paris, France). Abbreviations: W, WIN 55,212-2; SR, rimonabant; SEM, standard error of the mean; MPE, maximum possible effect. 


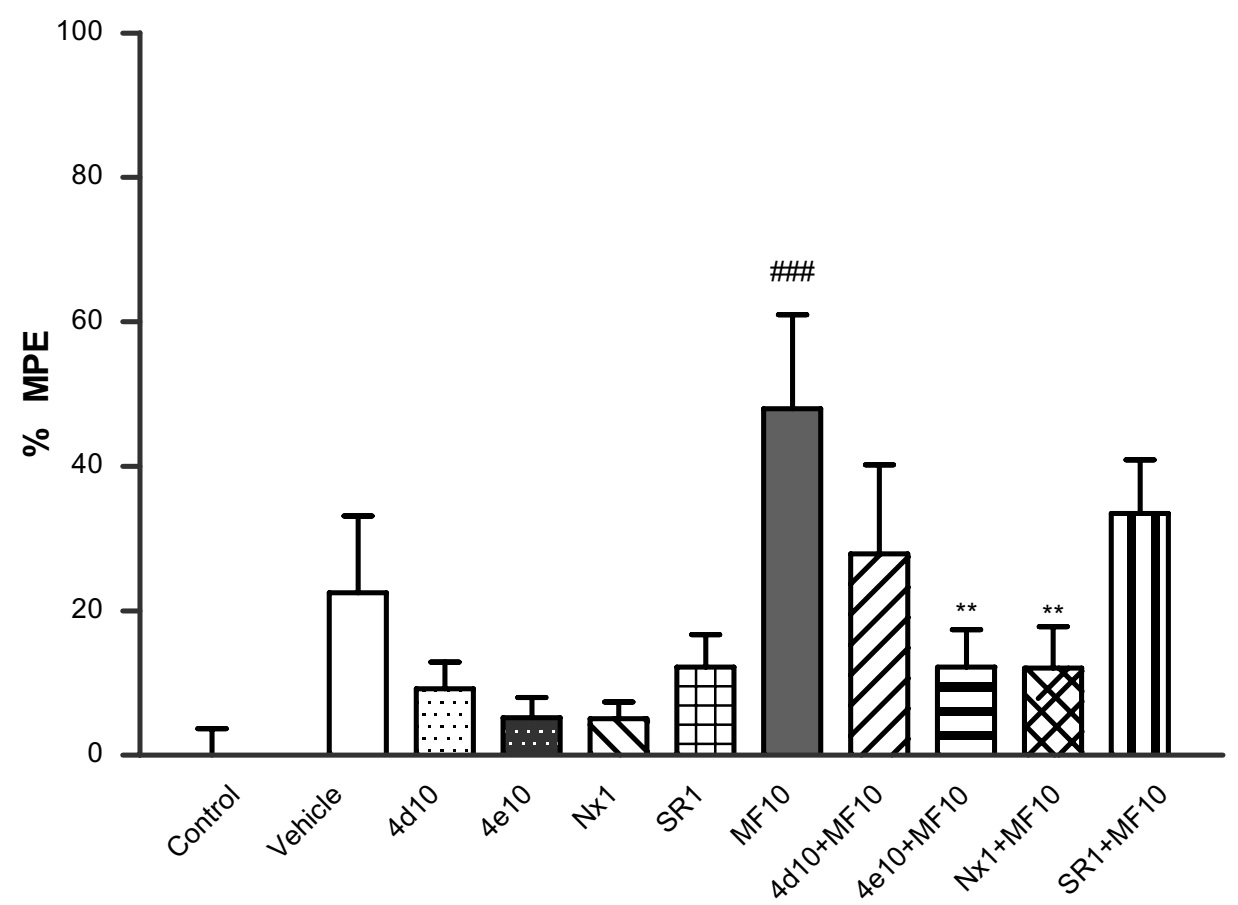

Figure 8 Antinociception: effects of $4 \mathrm{~d}$ and $4 \mathrm{e}$ on the hot plate test. Bars show percent MPE (mean $\pm \mathrm{SEM}, \mathrm{n} \leq 10$ ) induced by morphine $10 \mathrm{mg} / \mathrm{kg}, 4 \mathrm{~d} 10 \mathrm{mg} / \mathrm{kg}, 4 \mathrm{e} 10 \mathrm{mg} / \mathrm{kg}$, naloxone I mg/kg, and rimonabant I mg/kg administered 20 minutes after treatment with $4 \mathrm{~d} 10 \mathrm{mg} / \mathrm{kg}, 4 \mathrm{e} 10 \mathrm{mg} / \mathrm{kg}$, naloxone I mg/kg, or rimonabant I mg/kg. Statistically

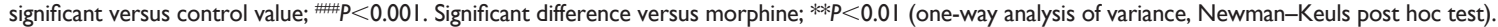

Notes: Morphine (Sigma-Aldrich, Madrid, Spain); naloxone (Tocris/Biogen Científica SL, Madrid, Spain); rimonabant (Sanofi, Paris, France).

Abbreviations: MF, morphine; Nx, naloxone; SEM, standard error of the mean; SR, rimonabant; MPE, maximum possible effect.

variations were focused on the linker separating the two pharmacophores, ie, aliphatic chains, cycloalkanes, and aromatic rings. Competitive binding assays and $\left[{ }^{35} \mathrm{~S}\right]-\mathrm{GTP} \gamma \mathrm{S}$ functionality tests were carried out in post-mortem human prefrontal cortex membrane preparations because receptors for both $\mathrm{CB}_{1}$ and $\mu$ opioids are expressed in this tissue, with the $\mathrm{CB}_{1}$ receptor being expressed in higher proportions. ${ }^{20}$ Selected compounds (4b, 4d, and 4e) displayed opioid and cannabinoid antagonism in these assays. Although the new compounds have modest affinity for both $\mathrm{CB} 1$ and $\mu$ receptors, an interesting finding is that $4 \mathrm{~b}, 4 \mathrm{~d}$, and $4 \mathrm{e}$ behaved as $\mathrm{CB}_{1}$ cannabinoid receptor antagonists with a potency similar to that of rimonabant.

Subsequently, the in vivo cannabinoid antagonism of $4 \mathrm{~d}$ and $4 \mathrm{e}$, based on behavioral effects in mice, support the $\left[{ }^{35} \mathrm{~S}\right]-\mathrm{GTP} \gamma \mathrm{S}$ bioassay results. With regard to their opioid properties in vivo, the hot plate test confirmed that $4 \mathrm{~d}$ and $4 \mathrm{e}$ had a $\mu$ opioid antagonist profile. In an alcohol relapse model in Wistar rats, treatment with $4 \mathrm{e}$ was not significantly effective in modulating relapse-like behavior.

Although these new compounds were designed as analogs of the opioid agonist fentanyl, the fact that they behave as opioid antagonists can be accounted for by subtle alteration of ligand structures that may lead to differences in affinity or intrinsic activity. However, these alterations occur more commonly with a morphine-like structure than with a fentanyl structure. While this paper was being prepared, Le Naour et $\mathrm{al}^{36}$ published on hybrid compounds based on rimonabant and morphine molecules. Unlike our case, the reported structural modification of morphine did not modify its opioid agonist nature.

The in silico ADME predictions for compound 4e suggest that it is likely to penetrate the blood-brain barrier, and this is consistent with the in vivo data.

In conclusion, this is the first description, to our knowledge, of hybrid compounds with cannabinoid and opioid antagonist properties in vitro and/or in vivo. It has been suggested in the literature that coadministration of cannabinoid antagonists and $\mu$ opioid antagonists could offer therapeutic advantages. ${ }^{27-29}$ Opioid-cannabinoid interactions in the regulation of appetite are of particular interest. Very recently, Wright and Rodgers ${ }^{30}$ reported a study showing that the pruritic effect of rimonabant can be attenuated by the opioid receptor antagonist naloxone. In this context, the promising dual activity of the cannabinoid/ opioid compounds presented here offers an attractive starting point for future therapeutic applications.

\section{Acknowledgments}

This work was supported by grants from the Spanish Ministry of Economy and Competitivity (SAF2012-40075, 
SAF2009-12422, SAF2010-20521, SAF2011-26818), Red de Trastornos Adictivos (RETICS RD06/001), the Madrid Government (CANNAB-CM, S2010/BMD-2308), the University of the Basque Country (UFI 11/35), the Basque Government (IT-199-07, SAIOTEK S-PE10UN14), and the Instituto de Salud Carlos III, Centro de Investigación Biomédica en Red de Salud Mental, CIBERSAM. AME is the recipient of a predoctoral fellowship from the Basque Government. PM is the recipient of a fellowship (JAE-Pre-2010-01119) from Junta para la Ampliación de Estudios, cofinanced by the European Social Fund. The authors thank Laura Hernández-Folgado for her help in preparation of the manuscript.

\section{Disclosure}

The authors report no conflicts of interest in this work.

\section{References}

1. Manzanares J, Corchero J, Romero J, Fernandez-Ruiz JJ, Ramos JA, Fuentes JA. Pharmacological and biochemical interactions between opioids and cannabinoids. Trends Pharmacol Sci. 1999;20(7): 287-294.

2. Vigano D, Rubino T, Parolaro D. Molecular and cellular basis of cannabinoid and opioid interactions. Pharmacol Biochem Behav. 2005;81(2):360-368.

3. Abrams DI, Couey P, Shade SB, Kelly ME, Benowitz NL. Cannabinoid-opioid interaction in chronic pain. Clin Pharmacol Ther. 2011;90(6):844-851.

4. Maldonado R, Berrendero F. Endogenous cannabinoid and opioid systems and their role in nicotine addiction. Curr Drug Targets. 2010;11(4): 440-449.

5. Christie MJ. Opioid and cannabinoid receptors: friends with benefits or just close friends? Br J Pharmacol. 2006;148(4):385-386.

6. Trang T, Sutak M, Jhamandas K. Involvement of cannabinoid (CB1)receptors in the development and maintenance of opioid tolerance. Neuroscience. 2007;146(3):1275-1288.

7. Scavone JL, Sterling RC, Van Bockstaele EJ. Cannabinoid and opioid interactions: Implications for opiate dependence and withdrawal. Neuroscience. 2013;248:637-654.

8. Morphy R, Rankovic Z. Designing multiple ligands - medicinal chemistry strategies and challenges. Curr Pharm Des. 2009;15(6): 587-600.

9. Shonberg J, Scammells PJ, Capuano B. Design strategies for bivalent ligands targeting GPCRs. Chem Med Chem. 2011;6(6):963-974.

10. Davis MP. Fentanyl for breakthrough pain: a systematic review. Expert Rev Neurother. 2011;11(8):1197-1216.

11. Jagerovic N, Fernandez-Fernandez C, Goya P. CB1 cannabinoid antagonists: structure-activity relationships and potential therapeutic applications. Curr Top Med Chem. 2008;8(3):205-230.

12. Christopoulou FD, Kiortsis DN. An overview of the metabolic effects of rimonabant in randomized controlled trials: potential for other cannabinoid 1 receptor blockers in obesity. J Clin Pharm Ther. 2011;36(1): 10-18.

13. Montero A, Goya P, Jagerovic N, et al. Guanidinium and aminoimidazolinium derivatives of $\mathrm{N}$-(4-piperidyl)propanamides as potential ligands for mu opioid and I2-imidazoline receptors: synthesis and pharmacological screening. Bioorg Med Chem. 2002;10(4):1009-1018.

14. Dardonville C, Fernandez-Fernandez C, Gibbons SL, et al. Synthesis and pharmacological studies of new hybrid derivatives of fentanyl active at the mu-opioid receptor and I-2-imidazoline binding sites. Bioorg Med Chem. 2006;14(19):6570-6580.
15. Thomas BF, Francisco MEY, Seltzman HH, et al. Synthesis of longchain amide analogs of the cannabinoid CB1 receptor antagonist $\mathrm{N}$-(piperidinyl)-5-(4-chlorophenyl)-1-(2,4-dichlorophenyl)-4-methyl1H-py razole-3-carboxamide (SR141716) with unique binding selectivities and pharmacological activities. Bioorg Med Chem. 2005;13(18): 5463-5474.

16. Fernandez-Fernandez C, Decara J, Bermúdez-Silva FJ, et al. Description of a bivalent cannabinoid ligand with hypophagic properties. Arch Pharm. 2013;346(3):171-179.

17. Sasmal PK, Reddy DS, Talwar R, et al. Novel pyrazole-3-carboxamide derivatives as cannabinoid-1 (CB1) antagonists: journey from non-polar to polar amides. Bioorg Med Chem Lett. 2011;21(1):562-568.

18. Dardonville C, Jagerovic N, Callado LF, Meana JJ. Fentanyl derivatives bearing aliphatic alkaneguanidinium moieties: a new series of hybrid molecules with significant binding affinity for mu-opioid receptors and I2imidazoline binding sites. Bioorg Med Chem Lett. 2004;14(2):491-493.

19. Krishnamurthy M, Li W, Moore BM 2nd. Synthesis, biological evaluation, and structural studies on N1 and C5 substituted cycloalkyl analogues of the pyrazole class of CB1 and CB2 ligands. Bioorg Med Chem. 2004;12(2):393-404.

20. De Jesus ML, Salles J, Meana JJ, Callado LF. Characterization of CB1 cannabinoid receptor immunoreactivity in postmortem human brain homogenates. Neuroscience. 2006;140(2):635-643.

21. Cumella J, Hernandez-Folgado L, Giron R, et al. Chromenopyrazoles: non-psychoactive and selective CB1 cannabinoid agonists with peripheral antinociceptive properties. ChemMedChem. 2012;7(3):452-463.

22. Gonzalez-Maeso J, Rodriguez-Puertas R, Gabilondo AM, Meana JJ. Characterization of receptor-mediated $\left[{ }^{35} \mathrm{~S}\right] \mathrm{GTP}$ gammaS binding to cortical membranes from postmortem human brain. Eur J Pharmacol. 2000;390(1-2):25-36.

23. Pertwee RG. The ring test: a quantitative method for assessing the 'cataleptic' effect of cannabis in mice. Br J Pharmacol. 1972;46(4): 753-763.

24. Serra S, Carai MA, Brunetti G, et al. The cannabinoid receptor antagonist SR 141716 prevents acquisition of drinking behavior in alcoholpreferring rats. Eur J Pharmacol. 2001;430(2-3):369-371.

25. Erdozain AM, Diez-Alarcia R, Meana JJ, Callado LF. The inverse agonist effect of rimonabant on $\mathrm{G}$ protein activation is not mediated by the cannabinoid $\mathrm{CB} 1$ receptor: evidence from postmortem human brain. Biochem Pharmacol. 2012;83(2):260-268.

26. Rowland NE, Mukherjee M, Robertson K. Effects of the cannabinoid receptor antagonist SR 141716, alone and in combination with dexfenfluramine or naloxone, on food intake in rats. Psychopharmacology. 2001;159(1):111-116.

27. Robledo P, Berrendero F, Ozaita A, Maldonado R. Advances in the field of cannabinoid-opioid cross-talk. Addict Biol. 2008;13(2):213-224.

28. Tallett AJ, Blundell JE, Rodgers RJ. Effects of acute low-dose combined treatment with naloxone and AM 251 on food intake, feeding behaviour and weight gain in rats. Pharmacol Biochem Behav. 2009;91(3): 358-366.

29. Wright FL, Rodgers RJ. Low dose naloxone attenuates the pruritic but not anorectic response to rimonabant in male rats. Psychopharmacology. 2013;226(2):415-431.

30. Pertwee RG, Stevenson LA, Elrick DB, Mechoulam R, Corbett AD. Inhibitory effects of certain enantiomeric cannabinoids in the mouse vas deferens and the myenteric plexus preparation of guinea-pig small intestine. Br J Pharmacol. 1992;105(4):980-984.

31. Heyser CJ, Moc K, Koob GF. Effects of naltrexone alone and in combination with acamprosate on the alcohol deprivation effect in rats. Neuropsychopharmacology. 2003;28(8):1463-1471.

32. Lopez-Moreno JA, Gonzalez-Cuevas G, Rodriguez de Fonseca F, Navarro M. Long-lasting increase of alcohol relapse by the cannabinoid receptor agonist WIN 55,212-2 during alcohol deprivation. J Neurosci. 2004;24(38):8245-8252.

33. Bowen JP, Guner OF. A perspective on quantum mechanics calculations in ADMET predictions. Curr Top Med Chem. 2013;13(11): 1257-1272. 
34. Lipinski CA, Lombardo F, Dominy BW, Feeney PJ. Experimental and computational approaches to estimate solubility and permeability in drug discovery and development settings. Adv Drug Deliv Rev. 2001;46(1-3):3-26.

35. Jorgensen WL, Duffy EM. Prediction of drug solubility from structure. Adv Drug Deliv Rev. 2002;54(3):355-366.
36. Le Naour M, Akgun E, Yekkirala A, et al. Bivalent ligands that target mu opioid (MOP) and cannabinoid1 (CB) receptors are potent analgesics devoid of tolerance. J Med Chem . 2013;56(13):5505-5513. 


\section{Supplementary material}

\section{Synthesis procedures}

and characterization of new compounds

General

Melting points were determined with a Reichert Jung Thermovar apparatus (Reichert Optische Werke, Vienna, Austria). Mass spectra (MS) were recorded using electrospray positive mode. Elemental analysis was performed on a Heraeus CHN-O rapid analyzer (Foss Heraeus GmbH, Hanau, Germany). Analyses indicated by symbols of the elements or functions were within $\pm 0.4 \%$ of theoretical values. Analytical high-performance liquid chromatography (HPLC) was run on a Waters 6000 with a Delta Pak C $18.5 \mu \mathrm{m}$ (Waters, Cerdanyola del Vallès, Spain), $300 \AA$, $3.9 \times 150 \mathrm{~mm}$ column, using $\mathrm{CH}_{3} \mathrm{CN} / \mathrm{H}_{2} \mathrm{O} 95 / 5(0.05 \%$ trifluoroacetic acid [TFA]) as eluent; flow rate $1 \mathrm{~mL}$ per minute; $254 \mathrm{~nm}$. Nuclear magnetic resonance (NMR, ${ }^{1} \mathrm{H},{ }^{13} \mathrm{C}$ ) spectra were recorded on Varian 300 (Agilent, Barcelona, Spain) and 400 unity spectrometers. All chemical shifts are reported in ppm. s: singlet; t: triplet; m: multiplet; brt: broad triplet; dp: double quadruplet; brm: broad multiplet; p: pentuplet; q: quadruplet; brd: broad doublet; brs: broad signal.

5-(4-Chlorophenyl)- I-(2,4-dichlorophenyl)-4-methyl$\mathrm{N}$-(3-(N-(I-phenethylpiperidin-4yl)propionamido) propyl)- I H-pyrazole-3-carboxamide (4a)

5-(4-Chlorophenyl)-1-(2,4-dichlorophenyl)-4-methyl-1 $H$ pyrazole-3-carbonyl chloride (2) (60 mg, $0.15 \mathrm{mmol}$ ), TEA (triethylamine) $(26 \mu \mathrm{L}, 0.19 \mathrm{mmol})$ and $N$-(3-aminopropyl)$N$-(1-phenethylpiperidin-4-yl)propionamide (3a) $(82 \mathrm{mg}$, $0.11 \mathrm{mmol}$ ), affording 4a as a yellow oil (44\%): ${ }^{1} \mathrm{H}$ NMR (399.93 $\left.\mathrm{MHz}, \mathrm{CDCl}_{3}\right) \delta 7.43-7.04(\mathrm{~m}, 12 \mathrm{H}), 4.46(\mathrm{~m}, 1 \mathrm{H}), 3.43(\mathrm{~m}, 2 \mathrm{H})$, $3.37(\mathrm{t}, 2 \mathrm{H}, J=7.1 \mathrm{~Hz}), 3.28(\mathrm{~m}, 2 \mathrm{H}), 3.1(\mathrm{~m}, 2 \mathrm{H}), 2.77(\mathrm{~m}, 2 \mathrm{H})$, $2.59(\mathrm{~m}, 2 \mathrm{H}), 2.35(\mathrm{~s}, 3 \mathrm{H}), 2.32(\mathrm{~m}, 2 \mathrm{H}), 2.05(\mathrm{~m}, 2 \mathrm{H}), 1.84$ (m, 2H), 1.69 (m, 2H), 1.10 (t, 3H, J=7.3 Hz); ${ }^{13} \mathrm{C}$ NMR (99.98 $\left.\mathrm{MHz}, \mathrm{CDCl}_{3}\right) \delta 173.7,162.8,145.2,142.8,140.1,136.0,135.7$, $134.9,132.9,130.8,130.6,130.2,128.9,128.8,128.6,128.4$, 127.8, 126.1, 117.5, 60.3, 55.3, 53.2, 51.5, 41.1, 39.4, 36.9, 33.8,

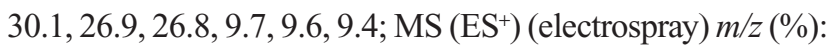
$680(100)[\mathrm{M}+\mathrm{H}]^{+} ;$HPLC $99 \%$ purity; anal. (elemental analysis) C36H40Cl3N5O2.H2O (C, H, N, O).

5-(4-Chlorophenyl)- I-(2,4-dichlorophenyl)-4-methyl$\mathrm{N}$-(4-(N-(I-phenethylpiperidin-4-yl)propionamido)

butyl)- I $\mathrm{H}$-pyrazole-3-carboxamide (4b)

5-(4-Chlorophenyl)-1-(2,4-dichlorophenyl)-4-methyl-1

$H$-pyrazole-3-carbonyl chloride (2) $(60 \mathrm{mg}, 0.15 \mathrm{mmol})$,
TEA $(26 \mu \mathrm{L}, 0.19 \mathrm{mmol})$ and $N$-(4-aminobutyl)- $N$-(1phenethylpiperidin-4-yl)propionamide (3b) $(63 \mathrm{mg}$, $0.19 \mathrm{mmol}$ ), affording $4 \mathrm{~b}$ as a yellowish solid (99\%): melting point $80^{\circ} \mathrm{C}-82^{\circ} \mathrm{C}$; ${ }^{1} \mathrm{H}$ NMR $\left(399.93 \mathrm{MHz}, \mathrm{CDCl}_{3}\right) \delta 7.42-$ $7.05(\mathrm{~m}, 12 \mathrm{H}), 4.51(\mathrm{~m}, 1 \mathrm{H}), 3.43(\mathrm{~m}, 2 \mathrm{H}), 3.23(\mathrm{~m}, 2 \mathrm{H})$, $2.89(\mathrm{~m}, 2 \mathrm{H}), 2.78(\mathrm{~m}, 2 \mathrm{H}), 2.61(\mathrm{~m}, 2 \mathrm{H}), 2.37(\mathrm{~s}, 3 \mathrm{H}), 2.32$ (m, 2H), $2.10(\mathrm{~m}, 2 \mathrm{H}), 1.92(\mathrm{~m}, 2 \mathrm{H}), 1.64(\mathrm{~m}, 2 \mathrm{H}), 1.12$ $(\mathrm{t}, 3 \mathrm{H}, J=7.3 \mathrm{~Hz}) ;{ }^{13} \mathrm{C}$ NMR $\left(99.98 \mathrm{MHz}, \mathrm{CDCl}_{3}\right) \delta 173.9$, 162.7, 145.0, 143.0, 139.9, 135.9, 135.8, 134.9, 132.9, 130.7, 130.5, 130.2, 129.1, 128.8, 128.8, 128.4, 126.1, 117.6, 60.2, 55.1, 53.1, 43.12, 38.2, 33.6, 30.6, 28.7, 27.3, 26.8, 9.7, 9.4; MS (ES') m/z (\%): $696(100)[\mathrm{M}+\mathrm{H}]^{+}$; HPLC 99\% purity; anal. $\mathrm{C} 37 \mathrm{H} 42 \mathrm{Cl} 3 \mathrm{~N} 5 \mathrm{O} 2.1 .5 \mathrm{H} 2 \mathrm{O}(\mathrm{C}, \mathrm{H}, \mathrm{N}, \mathrm{O})$.

5-(4-Chlorophenyl)- I-(2,4-dichlorophenyl)-4-methyl$\mathrm{N}$-(5-(N-(I-phenethyl piperidin-4-yl)propionamido) pentyl)- I H-pyrazole-3-carboxamide (4c)

5-(4-Chlorophenyl)-1-(2,4-dichlorophenyl)-4-methyl$1 \mathrm{H}$-pyrazole-3-carbonyl chloride (2) $(49 \mathrm{mg}, 0.12 \mathrm{mmol}$ ), TEA $(21 \mu \mathrm{L}, 0.15 \mathrm{mmol})$ and $N$-(5-aminopentyl)- $N$ (1-phenethylpiperidin-4-yl)propionamide (3c) $(52 \mathrm{mg}$, $0.15 \mathrm{mmol})$, affording $4 \mathrm{c}$ as a yellow solid $(73 \%)$ : ${ }^{1} \mathrm{H}$ NMR (399.93 MHz, $\mathrm{CDCl}_{3}$ ) (mixture of rotamers) $\delta 7.40-6.92(\mathrm{~m}, 12 \mathrm{H}), 5.80(\mathrm{~m}, 0.4 \mathrm{H}), 4.55(\mathrm{~m}, 0.3 \mathrm{H})$, $3.83(\mathrm{~m}, 0.6 \mathrm{H}), 3.70(\mathrm{~m}, 0.7 \mathrm{H}), 3.44(\mathrm{~m}, 2 \mathrm{H}), 3.10$ $(\mathrm{m}, 2 \mathrm{H}), 2.74(\mathrm{~m}, 2 \mathrm{H}), 2.56(\mathrm{~m}, 2 \mathrm{H}), 2.35(\mathrm{~s}, 3 \mathrm{H}), 2.30$ (m, 2H), 2.07 (m, 2H), $1.80(\mathrm{~m}, 2 \mathrm{H}), 1.65-1.30(\mathrm{~m}, 8 \mathrm{H})$, $1.12(\mathrm{~m}, 3 \mathrm{H}) ;{ }^{13} \mathrm{C}$ NMR $\left(99.98 \mathrm{MHz}, \mathrm{CDCl}_{3}\right) \delta 173.8$, 173.0, 162.7, 144.9, 138.8, 136.0, 134.9, 133.0, 130.8, $130.6,130.5,130.3,128.9,128.6,128.4,127.9,126.1$, 117.7, 60.4, 55.3, 53.3, 53.0, 43.3, 42.6, 38.7, 33.6, 30.7, 31.3, 29.5, 29.2, 9.8, 9.6, 9.4; MS (ES ${ }^{+} \mathrm{m} / z$ (\%): 710 (100) $[\mathrm{M}+\mathrm{H}]^{+}$; HPLC 99\% purity; anal. C38H44Cl3N5O2 (C, H, N, O).

5-(4-Chlorophenyl)- I-(2,4-dichlorophenyl)-4-methyl$\mathrm{N}$-(6-(N-(I-phenethy lpiperidin-4-yl)propionamido) hexyl)- I H-pyrazole-3-carboxamide (4d)

5-(4-Chlorophenyl)-1-(2,4-dichlorophenyl)-4-methyl-1 $H$-pyrazole-3-carbonyl chloride (2) $(60 \mathrm{mg}, 0.15 \mathrm{mmol})$, TEA $(26 \mu \mathrm{L}, 0.19 \mathrm{mmol})$ and $N$-(6-aminohexyl)- $N$ - $(1-$ phenethylpiperidin-4-yl)propionamide (3d) $(68 \mathrm{mg}$, $0.19 \mathrm{mmol})$, affording $4 \mathrm{~d}$ as a white solid (54\%): melting point $69^{\circ} \mathrm{C}-71^{\circ} \mathrm{C}$; ${ }^{1} \mathrm{H}$ NMR $\left(399.93 \mathrm{MHz}, \mathrm{CDCl}_{3}\right.$ ) (mixture of rotamers) $\delta 7.43-6.92(\mathrm{~m}, 12 \mathrm{H}), 4.46(\mathrm{~m}, 0.6 \mathrm{H})$, $3.55(\mathrm{~m}, 0.4 \mathrm{H}), 3.41(\mathrm{~m}, 2 \mathrm{H}), 3.20-3.04(\mathrm{~m}, 4 \mathrm{H}), 2.79(\mathrm{~m}, 2 \mathrm{H})$, $2.59(\mathrm{~m}, 2 \mathrm{H}), 2.37(\mathrm{~s}, 3 \mathrm{H}), 2.32(\mathrm{~m}, 2 \mathrm{H}), 2.06$ (brt, $2 \mathrm{H}$, 
$J=11.7 \mathrm{~Hz}), 1.86(\mathrm{dq}, 2 \mathrm{H}, J=3.4$ and $12.2 \mathrm{~Hz}), 1.68$ (brm, $2 \mathrm{H})$, 1.60, 1.54, 1.39 and $1.31(\mathrm{~m}, 8 \mathrm{H}), 1.14(\mathrm{~m}, 3 \mathrm{H}) ;{ }^{13} \mathrm{C} \mathrm{NMR}$ $\left(99.98 \mathrm{MHz}, \mathrm{CDCl}_{3}\right) \delta 173.7,162.7,145.0,143.1,140.1$, 136.0, 135.8, 134.9, 133.0, 130.8, 130.6, 130.5, 130.3, 128.9, $128.6,128.4,127.9,126.1,117.7,60.4,54.5,53.2,51.4,43.4$, 42.0, 38.8, 33.9, 30.9, 31.6, 30.0, 29.8, 26.9, 26.7, 26.6, 9.8, 9.7, 9.4; MS (ES+) m/z (\%): 724 (100) [M+H] $]^{+}$; HPLC 99\% purity; anal. C39H46C13N5O2 (C, H, N, O).

5-(4-Chlorophenyl)- I-(2,4-dichlorophenyl)-4-methyl$\mathrm{N}$-(7-(N-( I-phenethylpiperidin-4yl)propionamido) heptyl)- I H-pyrazole-3-carboxamide (4e)

5-(4-Chlorophenyl)-1-(2,4-dichlorophenyl)-4-methyl-1 $H$-pyrazole-3-carbonyl chloride (2) (60 mg, $0.15 \mathrm{mmol})$, TEA $(26 \mu \mathrm{L}, 0.19 \mathrm{mmol})$ and $N$-(7-aminoheptyl)- $N$ (1-phenethylpiperidin-4-yl)propionamide (3e) (41 mg, $0.11 \mathrm{mmol})$, affording $4 \mathrm{e}$ as an orange oil (55\%): ${ }^{1} \mathrm{H}$ NMR (399.93 MHz, $\mathrm{CDCl}_{3}$ ) (mixture of rotamers) $\delta 7.41-6.91(\mathrm{~m}$, $12 \mathrm{H}), 4.45(\mathrm{~m}, 0.7 \mathrm{H}), 3.53(\mathrm{~m}, 0.3 \mathrm{H}), 3.39(\mathrm{p}, 2 \mathrm{H}, J=7.0 \mathrm{~Hz})$, $3.17(\mathrm{t}, 2 \mathrm{H}, J=8.0 \mathrm{~Hz}), 3.10(\mathrm{~m}, 2 \mathrm{H}), 2.79(\mathrm{~m}, 2 \mathrm{H}), 2.60$ (m, 2H), 2.36 (s, 3H), 2.30 (m, 2H), 2.05 (brt, 2H, J=11.7 Hz), 1.84 (q, 2H, $J=11.3 \mathrm{~Hz}$ ), 1.67 (brd, 2H, $J=10.7 \mathrm{~Hz}$ ), 1.58, 1.51, $1.35,1.26(\mathrm{~m}, 10 \mathrm{H}), 1.30(\mathrm{~m}, 3 \mathrm{H}) ;{ }^{13} \mathrm{C} \mathrm{NMR}(99.98 \mathrm{MHz}$, $\left.\mathrm{CDCl}_{3}\right) \delta 173.7,172.9,162.6,145.0,143.0,140.1,135.9$, $135.8,134.8,132.9,130.8,130.5,130.3,117.6,60.4,55.2$, 53.1, 51.2, 43.4, 38.9, 38.8, 33.8, 29.6, 27.0, 26.9, 9.8, 9.6, 9.4, 42.1, 31.6, 30.8, 28.9, 27.1; $\mathrm{MS}\left(\mathrm{ES}^{+}\right) \mathrm{m} / z(\%): 738$ (100); $[\mathrm{M}+\mathrm{H}]^{+}$; HPLC 99\% purity; anal. C40H48Cl3N5O2.0.5H2O (C, H, N, O).

5-(4-Chlorophenyl)- I-(2,4-dichlorophenyl)-4-methylN-(8-(N-( I-phenethylpiperidin-4-yl)propionamido) octyl)- I H-pyrazole-3-carboxamide (4f)

5-(4-Chlorophenyl)-1-(2,4-dichlorophenyl)-4-methyl-1 $H$-pyrazole-3-carbonyl chloride (2) (60 mg, $0.15 \mathrm{mmol}$ ), TEA $(26 \mu \mathrm{L}, 0.19 \mathrm{mmol})$ and $N$-(8-aminooctyl)- $N$ (1-phenethylpiperidin-4-yl)propionamide (3f) (40 mg, 0.10 mmol), affording $4 \mathrm{f}$ as an orange solid (87\%): melting point $59^{\circ} \mathrm{C}-60^{\circ} \mathrm{C}$; ${ }^{1} \mathrm{H} \mathrm{NMR}\left(399.93 \mathrm{MHz}, \mathrm{CDCl}_{3}\right.$ ) (mixture of rotamers) $\delta 7.40-6.93(\mathrm{~m}, 12 \mathrm{H}), 4.45(\mathrm{~m}, 0.8 \mathrm{H}), 3.45$ $(\mathrm{m}, 0.2 \mathrm{H}), 3.38(\mathrm{~m}, 2 \mathrm{H}), 3.12(\mathrm{~m}, 2 \mathrm{H}), 3.04(\mathrm{~m}, 2 \mathrm{H}), 2.79(\mathrm{~m}$, $2 \mathrm{H}), 2.61(\mathrm{~m}, 2 \mathrm{H}), 2.35(\mathrm{~s}, 3 \mathrm{H}), 2.31(\mathrm{~m}, 2 \mathrm{H}), 2.02(\mathrm{~m}, 2 \mathrm{H})$, $1.87(\mathrm{~m}, 2 \mathrm{H}), 1.68(\mathrm{~m}, 2 \mathrm{H}), 1.56-1.28(\mathrm{~m}, 12 \mathrm{H}), 1.13(\mathrm{~m}, 3 \mathrm{H})$; ${ }^{13} \mathrm{C} \mathrm{NMR}\left(99.98 \mathrm{MHz} \mathrm{CDCl}_{3}\right) \delta 173.8,172.9,162.6,145.1$, 144.8, 140.5, 136.0, 134.9, 133.0, 130.8, 130.5, 130.3, 128.9, 128.6, 128.4, 127.9, 126.1, 117.7, 60.4, 53.3, 53.2, 43.5, 39.0, $33.9,31.7,30.9,29.3,29.2,27.2,29.7,26.9,26.7,9.8,9.6$,
9.4; $\mathrm{MS}\left(\mathrm{ES}^{+}\right) \mathrm{m} / z(\%): 750(100)[\mathrm{M}+\mathrm{H}]^{+} ; \mathrm{HPLC} 98 \%$ purity; anal. C41H50C13N5O2.H2O (C, H, N, O).

5-(4-Chlorophenyl)- I-(2,4-dichlorophenyl)-4-methylN-(9-(N-( I-phenethylpiperidin-4-yl)propionamido) nonyl)- I H-pyrazole-3-carboxamide (4g)

5-(4-Chlorophenyl)-1-(2,4-dichlorophenyl)-4-methyl-1 $H$-pyrazole-3-carbonyl chloride (2) (60 mg, $0.15 \mathrm{mmol})$, TEA $(26 \mu \mathrm{L}, 0.19 \mathrm{mmol})$ and $N$-(9-aminononyl)- $N$ (1-phenethylpiperidin-4-yl)propionamide (3g) $(30 \mathrm{mg}$, $0.07 \mathrm{mmol})$ affording $4 \mathrm{~g}$ as a yellow oil (85\%): ${ }^{1} \mathrm{H}$ NMR (399.93 $\mathrm{MHz}, \mathrm{CDCl}_{3}$ ) (mixture of rotamers) $\delta 7.73-6.92$ $(\mathrm{m}, 12 \mathrm{H}), 4.45(\mathrm{~m}, 0.7 \mathrm{H}), 3.53(\mathrm{~m}, 0.3 \mathrm{H}), 3.39,3.10$ (m, 2H), $3.07(\mathrm{~m}, 2 \mathrm{H}), 2.80(\mathrm{~m}, 2 \mathrm{H}), 2.57(\mathrm{~m}, 2 \mathrm{H}), 2.35$ (s, 3H), $2.30(\mathrm{~m}, 2 \mathrm{H}), 2.08(\mathrm{~m}, 2 \mathrm{H}), 1.84(\mathrm{q}, 2 \mathrm{H}, J=12.2 \mathrm{~Hz})$, $1.67(\mathrm{~m}, 2 \mathrm{H}), 1.58,1.49$ and $1.26(\mathrm{~m}, 14 \mathrm{H}), 1.13(\mathrm{~m}, 3 \mathrm{H})$; ${ }^{13} \mathrm{C} \mathrm{NMR}\left(99.98 \mathrm{MHz}, \mathrm{CDCl}_{3}\right) \delta 173.7,172.9,162.6,145.1$, $143.1,135.9,134.8,132.9,130.8,130.6,130.5,130.3,128.9$, 128.6, 128.4, 127.8, 127.2, 60.4, 55.3, 53.2, 51.4, 43.5, 39.0, 33.8, 31.6, 30.9, 30.0, 29.5, 29.2, 27.3, 27.2, 26.7, 26.9, 9.8, 9.6, 9.4; MS (ES $\left.{ }^{+}\right)$m/z (\%): 764 (100) $[\mathrm{M}+\mathrm{H}]^{+}$; HPLC 98\% purity; anal. C42H52Cl3N5O2.1.25H2O (C, H, N, O).

5-(4-Chlorophenyl)- I-(2,4-dichlorophenyl)-4-methyl$\mathrm{N}-(\mid$ 2-(N-(I-phenethylpiperidin-4-y|)propionamido) dodecyl)-I $\mathrm{H}$-pyrazole-3-carboxamide (4h)

5-(4-Chlorophenyl)-1-(2,4-dichlorophenyl)-4-methyl-1 $H$-pyrazole-3-carbonyl chloride (2) $(60 \mathrm{mg}, 0.15 \mathrm{mmol})$, TEA $(26 \mu \mathrm{L}, 0.19 \mathrm{mmol})$ and $N$-(12-aminododecyl)- $N$-(1phenethylpiperidin-4-yl)propionamide (3h) (78 mg, 0.19 mmol), affording $4 \mathrm{~h}$ as an orange oil (99\%): ${ }^{1} \mathrm{H} \mathrm{NMR} \mathrm{(399.93}$ $\left.\mathrm{MHz}, \mathrm{CDCl}_{3}\right) \delta 7.40-6.91(\mathrm{~m}, 12 \mathrm{H}), 4.41(\mathrm{~m}, 1 \mathrm{H}), 3.36$ (q, 2H, J=7.5 Hz), 3.14-2.96 (m, 4H), $2.78(\mathrm{~m}, 2 \mathrm{H}), 2.58(\mathrm{~m}$, $2 \mathrm{H}), 2.30(\mathrm{~m}, 3 \mathrm{H}), 2.23(\mathrm{~m}, 2 \mathrm{H}), 1.97(\mathrm{~m}, 2 \mathrm{H}), 1.80(\mathrm{~m}, 2 \mathrm{H})$, $1.62(\mathrm{~m}, 2 \mathrm{H}), 1.55-1.19(\mathrm{~m}, 20 \mathrm{H}), 1.08(\mathrm{~m}, 3 \mathrm{H}) ;{ }^{13} \mathrm{C} \mathrm{NMR}$ $\left(99.98 \mathrm{MHz}, \mathrm{CDCl}_{3}\right) \delta 174.2,173.3,163.0,145.5,143.4$, 136.4, 136.3, 135.3, 133.4, 131.2, 130.9, 130.7, 129.3, 129.1, $128.9,128.3,127.8,126.5,118.1,60.9,55.7,53.8,53.7,53.5$, 44.1, 42.7, 39.5, 34.26, 31.4, 30.2, 29.9, 29.8, 29.7, 27.8, 27.7,

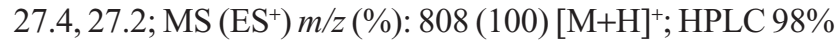
purity; anal. $\mathrm{C} 45 \mathrm{H} 58 \mathrm{Cl} 3 \mathrm{~N} 5 \mathrm{O} 2 . \mathrm{H} 2 \mathrm{O}(\mathrm{C}, \mathrm{H}, \mathrm{N}, \mathrm{O})$.

5-(4-Chlorophenyl)- I-(2,4-dichlorophenyl)-4-methyl$\mathrm{N}$-(3-(N-(I-phenethylpiperidin-4-yl)propionamido) phenyl)-I $\mathrm{H}$-pyrazole-3-carboxamide (4i) 5-(4-Chlorophenyl)-1-(2,4-dichlorophenyl)-4-methyl-1 $H$-pyrazole-3-carbonyl chloride (2) (60 mg, $0.15 \mathrm{mmol}$ ), TEA 
(15 $\mu \mathrm{L}, 0.11 \mathrm{mmol})$ and $N$-(3-aminophenyl)- $N$-(1-phenethylpiperidin-4-yl)propionamide (3i) (35 $\mathrm{mg}, 0.09 \mathrm{mmol}$ ), affording $4 \mathrm{i}$ as a yellow solid (48\%): melting point $105^{\circ} \mathrm{C}-108^{\circ} \mathrm{C}$; ${ }^{1} \mathrm{H}$ NMR (399.93 MHz, $\mathrm{CDCl}_{3}$ ) $\delta 7.53-6.73(\mathrm{~m}, 16 \mathrm{H}), 4.58$ (m, 1H), 2.91 (brs, 2H, J=10.5 Hz), 2.61 (m, 2H), 2.43 (m, 2H), 2.33 (s, 3H), 2.07 (brt, 2H, $J=11.5 \mathrm{~Hz}), 1.91$ (m, 2H), 1.75 (brt, 2H, J=14.0 Hz), 1.39 (m, 2H), 0.94 (t, 3H, $J=7.5$ $\mathrm{Hz}) ;{ }^{13} \mathrm{C} \mathrm{NMR}\left(99.98 \mathrm{MHz}, \mathrm{CDCl}_{3}\right) \delta 173.4,160.5,144.5$, $143.6,139.5,138.9,136.2,135.7,135.1,133.0,132.9,130.8$, $130.5,130.4,129.6,129.0,128.6,128.3,127.9,126.8,126.0$, $125.8,121.4,119.2,118.3,60.4,53.1,52.2,33.8,30.6,28.5$, 9.6, 9.5; MS (ES+) m/z (\%): $716(100)[\mathrm{M}+\mathrm{H}]^{+}$; HPLC 99\% purity; anal. C39H38C13N5O2.3H2O (C, H, N, O).

5-(4-Chlorophenyl)- I-(2,4-dichlorophenyl)-4-methyl$\mathrm{N}$-(3-(N-(I-phenethylpiperidin-4yl)propionamido) benzyl)-I H-pyrazole-3-carboxamide (4j)

5-(4-Chlorophenyl)-1-(2,4-dichlorophenyl)-4-methyl-1 $H$-pyrazole-3-carbonyl chloride (2) (60 mg, $0.15 \mathrm{mmol})$, TEA (26 $\mu \mathrm{L}, 0.19 \mathrm{mmol})$ and $N$-(3-(aminomethyl)benzyl)$N$-(1-phenethylpiperidin-4-yl)propionamide (3j) (60 mg, $0.15 \mathrm{mmol}$ ), affording $4 \mathrm{j}$ as a yellow solid $(60 \%)$ : melting point $83^{\circ} \mathrm{C}-85^{\circ} \mathrm{C}$; ${ }^{1} \mathrm{H}$ NMR $\left(399.93 \mathrm{MHz}, \mathrm{CDCl}_{3}\right)$ (mixture of rotamers) $\delta 7.40-7.06(\mathrm{~m}, 16 \mathrm{H}), 4.60(\mathrm{~m}$, $4 \mathrm{H}), 4.51(\mathrm{~m}, 1 \mathrm{H}), 3.67(\mathrm{~m}, 1 \mathrm{H}), 3.00(\mathrm{~m}, 2 \mathrm{H}), 2.74(\mathrm{~m}$, 2H), 2.55 (m, 2H), 2.48 (q, 0.5H, J=7.3 Hz), 2.40 (s, 3H), 2.23 (q, 1.5H, J=7.3 Hz), $2.11(\mathrm{~m}, 2 \mathrm{H}), 1.79(\mathrm{~m}, 2 \mathrm{H}), 1.65$ $(\mathrm{m}, 2 \mathrm{H}), 1.20(\mathrm{t}, 1 \mathrm{H}, J=7.3 \mathrm{~Hz}), 1.07$ (t, 2H, $J=7.3 \mathrm{~Hz})$;
${ }^{13} \mathrm{C} \mathrm{NMR}\left(99.98 \mathrm{MHz}, \mathrm{CDCl}_{3}\right) \delta 174.7,173.9,162.6,144.7$, 143.1, 140.1, 139.1, 138.3, 136.0, 135.9, 134.9, 132.9, 130.8, $130.5,130.3,129.0,128.9,128.6,128.4,127.9,127.2,126.5$, $126.1,124.8,124.5,117.9,60.3,53.0,51.5,50.7,46.3$; MS $\left(\mathrm{ES}^{+}\right) \mathrm{m} / z(\%): 742(100)[\mathrm{M}+\mathrm{H}]^{+}$; HPLC 99\% purity; anal. C41H42N5O2.0.5H2O (C, H, N, O).

5-(4-Chlorophenyl)- I-(2,4-dichlorophenyl)-4-methyl$\mathrm{N}-(4-[(4-\mathrm{N}-(\mathrm{I}-$ phenethylpiperidin-4-yl)propionamido) cyclohexyl]methyl)cyclo-hexyl-I H-pyrazole-3carboxamide $(4 \mathrm{k})$

5-(4-Chlorophenyl)-1-(2,4-dichlorophenyl)-4-methyl-1 $H$-pyrazole-3-carbonyl chloride (2) (49 mg, $0.12 \mathrm{mmol}$ ), TEA $(21 \mu \mathrm{L}, 0.15 \mathrm{mmol})$ and $N$-(4-((4-aminocyclohexyl)methyl) cyclohexyl)- $N$-(1-phenethylpiperidin-4-yl)propionamide (3k) (70 $\mathrm{mg}, 0.15 \mathrm{mmol}$ ), affording $4 \mathrm{k}$ as a yellow solid $(73 \%):{ }^{1} \mathrm{H}$ NMR (399.93 MHz, $\left.\mathrm{CDCl}_{3}\right) \delta 7.36-6.69(\mathrm{~m}, 12 \mathrm{H}), 4.12(\mathrm{~m}$, $1 \mathrm{H}), 3.84(\mathrm{~m}, 1 \mathrm{H}), 3.47(\mathrm{~m}, 1 \mathrm{H}), 3.05(\mathrm{~m}, 2 \mathrm{H}), 2.57(\mathrm{~m}, 2 \mathrm{H})$, $2.53(\mathrm{~m}, 2 \mathrm{H}), 2.31(\mathrm{~s}, 3 \mathrm{H}), 2.27(\mathrm{~m}, 2 \mathrm{H}), 2.02(\mathrm{~m}, 2 \mathrm{H}), 1.86$ (m, 2H), $1.63(\mathrm{~m}, 2 \mathrm{H}), 1.99-1.31(\mathrm{~m}, 20 \mathrm{H}), 1.19(\mathrm{~m}, 3 \mathrm{H})$; ${ }^{13} \mathrm{C}$ NMR (99.98 MHz, $\left.\mathrm{CDCl}_{3}\right) \delta 172.8,161.9,145.2,142.9$, $140.0,136.0,135.9,134.8,132.9,130.8,130.6,130.3,128.8$, $128.6,128.4,127.8,126.1,117.7,60.5,56.0,53.3,48.5$, $45.5,37.5,34.4,33.1,32.1,32.0,29.6,29.3,33.8,28.6,24.5$, 9.6, 9.4; $\mathrm{MS}\left(\mathrm{ES}^{+}\right) \mathrm{m} / z(\%): 816(100)[\mathrm{M}+\mathrm{H}]^{+}$; HPLC 99\% purity; anal. $\mathrm{C} 46 \mathrm{H} 56 \mathrm{Cl} 3 \mathrm{~N} 5 \mathrm{O} 2.2 \mathrm{H} 2 \mathrm{O}(\mathrm{C}, \mathrm{H}, \mathrm{N}, \mathrm{O})$.
Drug Design, Development and Therapy

\section{Publish your work in this journal}

Drug Design, Development and Therapy is an international, peerreviewed open-access journal that spans the spectrum of drug design and development through to clinical applications. Clinical outcomes, patient safety, and programs for the development and effective, safe, and sustained use of medicines are a feature of the journal, which

\section{Dovepress}

has also been accepted for indexing on PubMed Central. The manuscript management system is completely online and includes a very quick and fair peer-review system, which is all easy to use. Visit http://www.dovepress.com/testimonials.php to read real quotes from published authors. 